Review

\title{
Invasive Fungal Infections Complicating COVID-19: A Narrative Review
}

\author{
Giacomo Casalini ${ }^{1}\left(\mathbb{D}\right.$, Andrea Giacomelli ${ }^{1,2}{ }^{(D}$, Annalisa Ridolfo ${ }^{2}$, Cristina Gervasoni ${ }^{2}$ \\ and Spinello Antinori $1,2, *$ (D)
}

1 Luigi Sacco Department of Biomedical and Clinical Sciences, Università degli Studi di Milano, 20157 Milan, Italy; giacomo.casalini@unimi.it (G.C.); andrea.giacomelli@unimi.it (A.G.)

2 III Division of Infectious Diseases, ASST Fatebenefratelli Sacco, 20157 Milan, Italy; annalisa.ridolfo@asst-fbf-sacco.it (A.R.); cristina.gervasoni@asst-fbf-sacco.it (C.G.)

* Correspondence: spinello.antinori@unimi.it; Tel.: +39-02-5031-9765; Fax: +39-02-5031-9758

Citation: Casalini, G.; Giacomelli, A.; Ridolfo, A.; Gervasoni, C.; Antinori, S Invasive Fungal Infections Complicating COVID-19: A Narrative Review. J. Fungi 2021, 7, 921. https://doi.org/10.3390/jof7110921

Academic Editors: Ana Fernandez Cruz and Eleni Magira

Received: 24 September 2021

Accepted: 28 October 2021

Published: 29 October 2021

Publisher's Note: MDPI stays neutral with regard to jurisdictional claims in published maps and institutional affiliations.

Copyright: (c) 2021 by the authors. Licensee MDPI, Basel, Switzerland. This article is an open access article distributed under the terms and conditions of the Creative Commons Attribution (CC BY) license (https:// creativecommons.org/licenses/by/ $4.0 /)$.

\begin{abstract}
Invasive fungal infections (IFIs) can complicate the clinical course of COVID-19 and are associated with a significant increase in mortality, especially in critically ill patients admitted to an intensive care unit (ICU). This narrative review concerns 4099 cases of IFIs in 58,784 COVID-19 patients involved in 168 studies. COVID-19-associated invasive pulmonary aspergillosis (CAPA) is a diagnostic challenge because its non-specific clinical/imaging features and the fact that the proposed clinically diagnostic algorithms do not really apply to COVID-19 patients. Forty-seven observational studies and 41 case reports have described a total of 478 CAPA cases that were mainly diagnosed on the basis of cultured respiratory specimens and/or biomarkers/molecular biology, usually without histopathological confirmation. Candidemia is a widely described secondary infection in critically ill patients undergoing prolonged hospitalisation, and the case reports and observational studies of 401 cases indicate high crude mortality rates of $56.1 \%$ and $74.8 \%$, respectively. COVID-19 patients are often characterised by the presence of known risk factors for candidemia such as in-dwelling vascular catheters, mechanical ventilation, and broad-spectrum antibiotics. We also describe 3185 cases of mucormycosis (including 1549 cases of rhino-orbital mucormycosis $(48.6 \%))$, for which the main risk factor is a history of poorly controlled diabetes mellitus $(>76 \%)$. Its diagnosis involves a histopathological examination of tissue biopsies, and its treatment requires anti-fungal therapy combined with aggressive surgical resection/debridement, but crude mortality rates are again high: $50.8 \%$ in case reports and $16 \%$ in observational studies. The presence of other secondary IFIs usually diagnosed in severely immunocompromised patients show that SARS-CoV-2 is capable of stunning the host immune system: 20 cases of Pneumocystis jirovecii pneumonia, 5 cases of cryptococcosis, 4 cases of histoplasmosis, 1 case of coccidioides infection, 1 case of pulmonary infection due to Fusarium spp., and 1 case of pulmonary infection due to Scedosporium.
\end{abstract}

Keywords: COVID-19; invasive fungal infections; aspergillosis; CAPA; candidemia; mucormycosis; CAM; PCP; histoplasmosis; cryptococcosis

\section{Introduction}

SARS-CoV-2, the causative agent of coronavirus disease 2019 (COVID-19), is responsible for a respiratory disease whose broad spectrum of severity ranges from asymptomatic or mildly symptomatic infection to severe bilateral pneumonia leading to progressive respiratory failure requiring non-invasive or invasive mechanical ventilation [1]. The death toll of COVID-19 is mainly due to extensive lung damage, although a number of studies have suggested that secondary pulmonary or non-pulmonary, bacterial, or fungal infections play a significant role [2,3]. Many factors may be associated with these secondary infections, including immune system dysregulation and inhibition, epithelial barrier damage, the widespread use of antibiotics, admission to an intensive care unit (ICU), mechanical ventilation, and prolonged hospitalisation $[1,2,4]$. The main etiological agents of secondary 
infections in COVID-19 are Gram-positive and Gram-negative bacteria, but some yeasts and moulds have also been described as deadly secondary pathogens [5].

Invasive pulmonary aspergillosis (IPA) is a life-threatening disease caused by the ubiquitous Aspergillus mould, which is typically associated with immune system dysregulation due to chronic glucocorticoid therapy, prolonged neutropenia in hematological patients, stem cell/solid organ transplantation, or immunosuppressive treatment [6]. Since the first reports of COVID-19 in Wuhan, some authors have highlighted the risk of invasive fungal infections (IFIs) in critically ill COVID-19 patients on the basis of the increasing number of reports of IPA in ICU patients without immunological disorders, such as those with severe influenza or chronic obstructive pulmonary disease [7-9]. Various published case reports and observational studies of COVID-19-associated IPA (CAPA) have raised concerns about the burden of this infection and difficulties in diagnosing it (non-specific clinical and radiological findings, the uncertain diagnostic performance of microbiological assays in an ICU, difficulties in differentiating colonisation from infections, the fact that the current clinical diagnostic algorithm does not really apply to COVID-19 patients, and concerns about collecting lower respiratory tract samples because of the risk of contagion) $[10,11]$.

Candidemia is a typical secondary infection of critically ill patients that is associated with prolonged mechanical ventilation, total parenteral nutrition, broad spectrum antibiotic treatment, in-dwelling blood catheters, glucocorticoid therapy, and abdominal surgery before ICU admission [12,13]. COVID-19 patients admitted to an ICU generally undergo prolonged mechanical ventilation due to severe acute respiratory distress syndrome (ARDS) and receive antimicrobials, and are therefore at greater risk of developing secondary candidemia, which has been reported in a number of studies of COVID-19 [14,15].

Mucormycosis is an invasive fungal infection (IFI) that is caused by caused by naturally ubiquitous filamentous Mucorales fungi. The factors predisposing for mucormycosis include uncontrolled diabetes mellitus, glucocorticoid treatment, malnutrition, and other immunosuppressive conditions [16,17], and an increasing number of reports (mainly from India) have indicated that mucormycosis can be detrimental in patients with ongoing or previous COVID-19, especially if they are diabetic or have poorly controlled glycemia [18].

Finally, Pneumocystis jirovecii pneumonia (PCP), cryptococcosis, and histoplasmosis are other IFIs that have been reported in COVID-19 patients, which suggests that SARS-CoV-2induced immune dysregulation can increase the likelihood of developing opportunistic infections typically seen in patients with severe immunodepression, such as acquired immunodeficiency syndrome (AIDS) or haematological malignancies [19].

The aim of this narrative review is to describe the characteristics of the IFIs complicating COVID-19 by separately analysing case reports and observational studies, with particular emphasis on the clinical and microbiological characteristics of CAPA and the clinical algorithms used to diagnose it.

\section{Materials and Methods}

The PubMed and Scopus databases were searched to find English, Italian, or Spanish case reports, case series, or retrospective or prospective observational studies of IFIs occurring in COVID-19 patients that were published between 1 January 2020 and 18 June 2021 using the following terms: (Aspergill* OR CAPA) AND (invasive OR putative OR probable OR infection OR case OR patient OR report) AND (COVID* OR corona* OR SARS-CoV-2); (Candida OR candidemia OR candidiasis) AND (infection OR case OR patient OR report) AND (COVID* OR corona* OR SARS-CoV-2); (mucormyc* OR rhizopus) AND (invasive OR putative OR probable OR infection OR case OR patient OR report) AND (COVID* OR corona* OR SARS-CoV-2); (pneumocyst*) AND (infection OR case OR patient OR report) AND (COVID* OR corona* OR SARS-CoV-2); (cryptococc*) AND (infection OR case OR patient OR report) AND (COVID* OR corona* OR SARS-CoV-2); (histoplasm*) AND (infection OR case OR patient OR report) AND (COVID* OR corona* OR SARS-CoV-2). Adults diagnosed with IFIs and COVID-19 were included, regardless of their age or origin, and, when available, their patient-level demographic, clinical, and microbiological data 
were extracted. The different IFIs are discussed separately, differentiating case reports and case series from retrospective and prospective observational studies. We also discuss the characteristics of CAPA and the applicability of its various clinically diagnostic algorithms.

\section{Results}

\subsection{COVID-19-Associated Pulmonary Aspergillosis}

The literature search identified 88 articles describing cases of CAPA: 47 observational studies (28 retrospective and 19 prospective) [2,10,11,20-63] and 41 case report/series [64-102]. Fifty-three studies were from European countries (mainly from France, 16 articles (30.2\%) and Italy, nine articles $(17 \%)$ ) and 34 from non-European countries (mainly the United States, six studies $(17.6 \%))$.

\subsubsection{Case Reports and Case Series}

Seventy-four patients with CAPA were reported, of which 42 (56.8\%) were classified as having "probable CAPA", $12(16.2 \%)$ as having "putative CAPA", five (6.8\%) as having "proven CAPA", and $15(20.3 \%)$ as having non-specified CAPA (Table 1; detailed information about the individual studies is given in Table S1). Most of the studies were conducted in ICUs $(92.7 \%)$, and 69 of the patients were mechanically ventilated (93.2\%). The main diagnostic criteria used were AspICU [103] (seven studies) and modified AspICU (eight studies) [104]. The patients were predominantly male $(49,66.2 \%)$ and had a median age of 69 years (inter-quartile range (IQR) 57-74). The reported major co-morbidities were arterial hypertension (37 patients, $50 \%$ ), diabetes mellitus $(26,35.1 \%)$, chronic pulmonary disease $(13,17.5 \%)$, cardiovascular disease $(9,12.2 \%)$, and obesity $(4,5.4 \%)$. It is worth noting chronic glucocorticoid exposure before COVID-19 and a CAPA diagnosis were reported in only three cases (one patient on chronic steroids for polymyalgia rheumatica, one solid organ transplant patient, and one patient with chronic obstructive pulmonary disease on inhaled steroids) $[67,70,82]$. Thirty-seven patients $(50 \%)$ received corticosteroids for COVID-19 pneumonia, and $10(13.5 \%)$ received at least one dose of tocilizumab. The median number of days from ICU admission or intubation to the diagnosis of CAPA was 13 (IQR 6-21).

Of the 72 patients for whom culture data were available, 62 had a respiratory culture positive for Aspergillus (86.1\%), mainly bronchoalveolar lavage $(25,40.3 \%)$ and bronchial aspirate specimens (20,32.3\%). The most frequently isolated Aspergillus species were $A$. fumigatus (43 cultures, $67.2 \%$ ) and $A$. niger ( 8 cultures, $12.5 \%$ ), and the most frequent diagnostic samples were bronchoalveolar lavage (BAL) samples (25, 40.3\%). Direct examination of respiratory samples showing septate branching hyphae was reported in 11 cases $(17.7 \%$ of positive cultures) $[65-67,71,76,86-89,92,96,102]$. Proven CAPA was reported in five studies: in three cases, the diagnosis was made post portem [69,72,95]; in the remaining two cases, the diagnosis was made using pulmonary tissue (biopsy in one case, lobectomy in the other) $[89,92]$. Serum galactomannan (GM) was positive (optical density index [ODI] $>0.5$ ) in $25 / 47$ cases $(53.2 \%)$ with a median value of 1.7 (IQR 1.1-3.1) (ODI index available in 21 cases). Respiratory sample GM was positive (ODI $>1$ ) in $27 / 29$ cases $(93 \%)$, with a median value of 4.4 (IQR 2.2-6.1) (ODI index available in 23 cases); the median ODI of the BAL samples was 4.6 (IQR 2.2-6.3). Chest computed tomography (CT) findings suggesting invasive pulmonary aspergillosis (IPA) were reported in only $24 / 72$ cases (33.3\%).

Ninety-two percent of the patients received anti-fungal treatment, and there were two pan-azole-resistant infections [75,76]. In the case reported by Mohammed et al. [75], the resistance of the A. fumigatus strain was determined by means of phenotype testing using a 4-well triazole resistance screen (VIP check ${ }^{\mathrm{TM}}$ ) and the minimum inhibitory concentrations (MIC) using gradient strips. Ghelfenstein-Ferreira et al. described an A. fumigatus strain with high MICs for all azoles and identified the TR34/L98H mutation [76].

The overall reported mortality rate was $52.7 \%(39 / 64)$. 
Table 1. Case reports and case series describing COVID-19-associated pulmonary aspergillosis (CAPA).

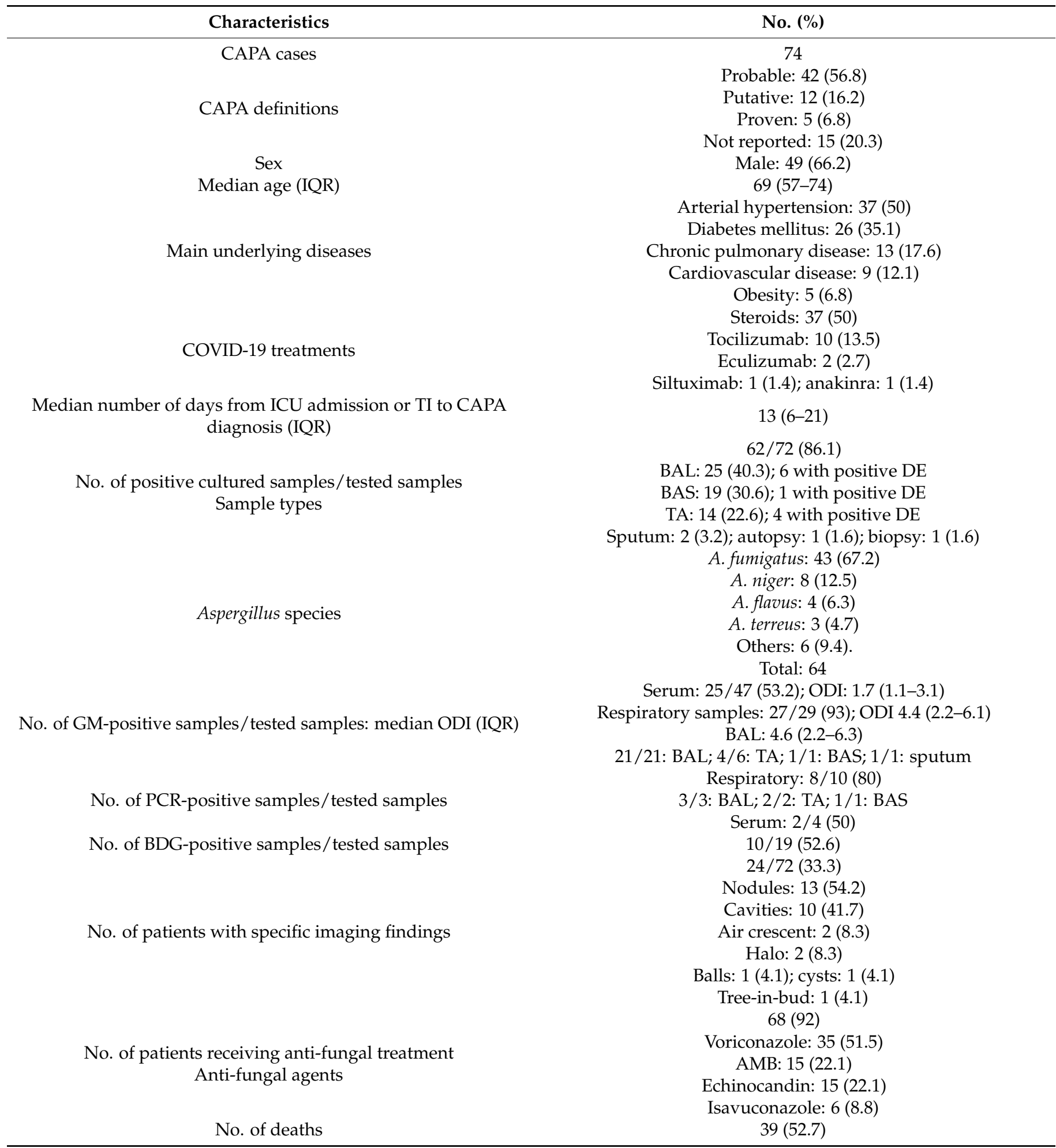

Data are absolute numbers (percentage) unless otherwise specified. Abbreviations: IQR, interquartile range; ICU, intensive care unit; TI, tracheal intubation; GM, galattomannan; ODI, optical density index; BAL, bronchial-alveolar lavage; BAS, bronchial aspirate; TA, tracheal aspirate; BDG, (1-3)- $\beta$-D-glucan; AMB, amphotericin B.

\subsubsection{Observational Studies}

Four hundred and four cases of CAPA were described in 47 observational studies of 12,080 COVID-19 patients (average incidence 3.3\%); the incidence of CAPA in the individual studies varied from $0.1 \%$ [28] to $57.1 \%$ [34] (Table 2; detailed information about 
the individual studies is given in Table S2). Most of the studies (85\%) exclusively involved critically ill patients requiring ICU admission.

Table 2. Observational studies reporting CAPA.

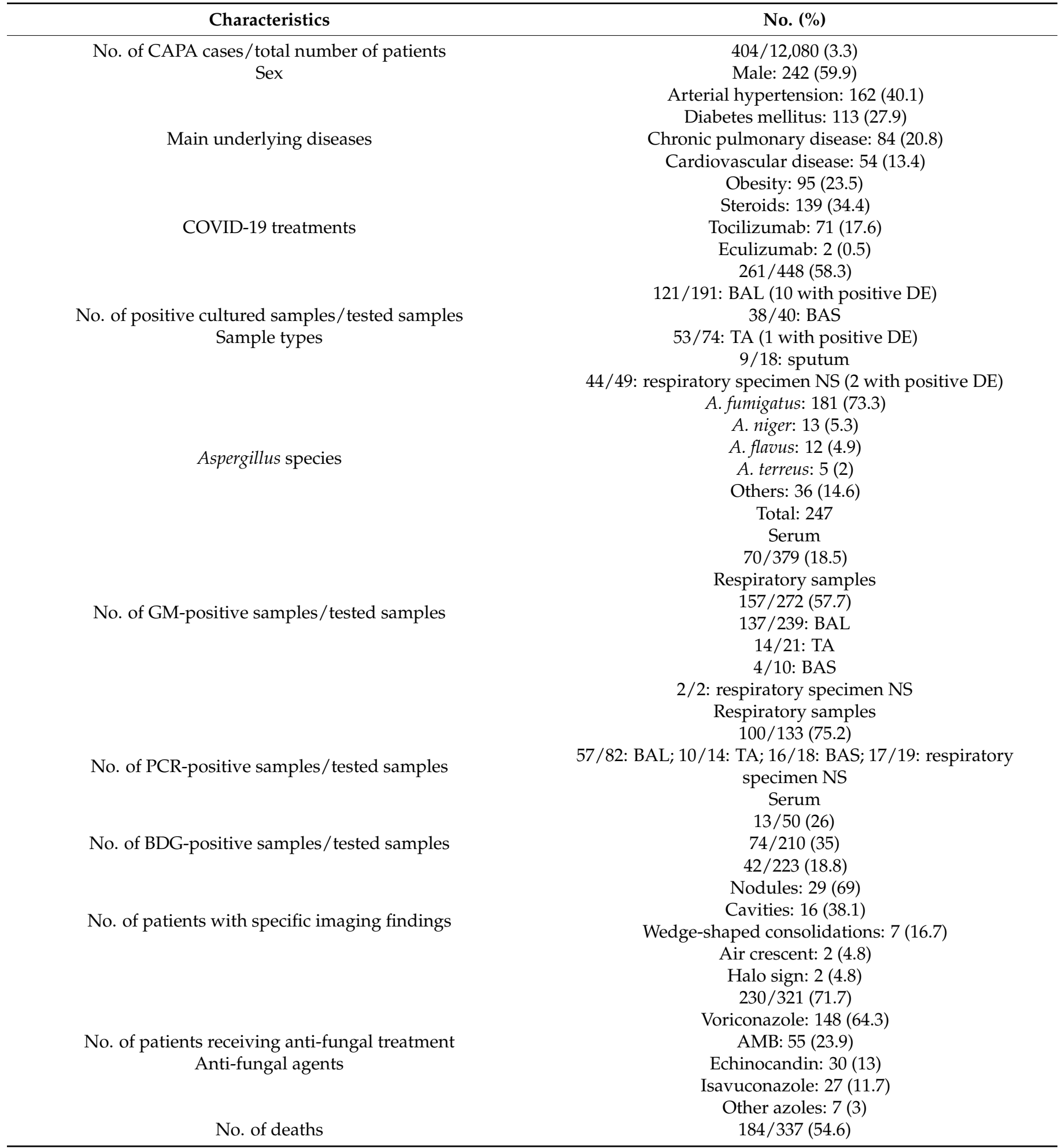

Data are absolute numbers (percentage) unless otherwise specified. Positive direct examination refers to the observation of septate branching hyphae in respiratory samples. Abbreviations. GM, galattomannan; ODI, optical density index; BAL, bronchial-alveolar lavage; BAS, bronchial aspirate; TA, tracheal aspirate; NS, not specified; BDG, (1-3)- $\beta$-D-glucan; AMB, amphotericin B. 
Given the lack of consensus concerning the criteria for defining CAPA, it was diagnosed using various case definitions and clinical algorithms, including the AspICU algorithm with or without modifications (14 studies) [103], the modified AspICU criteria (7 studies) [104], the influenza-associated IPA (IAPA) criteria of Schauwvlieghe et al. (8 studies) [105], the new CAPA criteria of White et al. (1 study) [30], the algorithm proposed by ECCM/ISHAM (6 studies) [106], and the European Organization for Research and Treatment of Cancer and the Mycoses Study Group Education and Research Consortium (EORTC/MSGE) algorithm (7 studies) [107]. Ten studies did not specify the criteria used to diagnose CAPA $[21,27,29,31,36,44,51,57,59,63]$.

The patients were mainly adult males (59.9\%); had a median age ranging from 33 to 78 years; and were affected by arterial hypertension ( $40.1 \%)$, chronic cardio-pulmonary diseases $(34.2 \%)$, and diabetes mellitus (27.9\%). One hundred and thirty-nine (34.4\%) received systemic corticosteroids, and $73(18.1 \%)$ targeted COVID-19 treatment (antiIL-6 drugs such as tocilizumab or eculizumab). Most of the patients were undergoing mechanical ventilation because of severe respiratory failure $(84.7 \%)$.

The majority $(58.3 \%)$ of the cultured samples were positive, with BAL samples being the most frequent (121/191 positive, $63.4 \%)$. The most frequently identified species was Aspergillus fumigatus (73.3\%), followed by A. niger (5.3\%), A. flavus (4.9\%), and A. terreus $(2 \%)$. Direct examination of respiratory sample showing septate branching hyphae was reported in 13 cases ( $4.9 \%$ of positive cultures), mainly BAL samples [24,33,35,43,47,52,54]. Serum GM was positive in only $70 / 379$ cases $(18.5 \%)$, with median ODI values ranging from 0.51 to 3.1 . GM was positive in $157 / 272$ respiratory samples $(57.7 \%)$. One hundred and thirty-seven of the 239 tested BAL samples were GM positive (57.3\%), with median ODI values ranging from 1 to 6.4. Aspergillus-specific polymerase chain reaction (PCR) testing of serum and respiratory samples was used in 16 studies and proved to be positive in $75.2 \%$ of the respiratory samples (mainly BAL, $69.5 \%$ ) and $26 \%$ of the serum samples. Serum $(1,3) \beta$-D-glucan (BDG) was positive more frequently than serum GM (35\%) (Table 2).

Histopathological or cytological findings were considered in eight studies involving 16 patients: fungal hyphae were detected in the respiratory specimens of 10 (nine BAL, one TA) $[33,35,43,47,52,55]$, trans-bronchial pulmonary biopsy led to a diagnosis of "proven CAPA" in four [24], and the diagnosis was confirmed by means of autopsy in two [20].

As in the case reports and CAPA patient series, chest CT findings suggested IPA was rarely used in the observational studies ( $18.8 \%$ of cases): the main findings were nodules $(69 \%)$, cavities $(38.1 \%)$, and wedge-shaped consolidations (16.7\%).

Anti-fungal treatment was received by $71.7 \%$ of the patients (voriconazole in $64.3 \%$ of cases). It is worth noting that two studies reported three cases of azole-resistant AspergillusMachado et al. described a voriconazole-resistant isolate of A. lentulus (MIC $2 \mathrm{mg} / \mathrm{L}$ ) [39], and Meijer et al. described two azole-resistant isolates of A. fumigatus that were positive to the VIPCheck test and molecular biology for the TR34/L98H mutation [49].

The reported crude mortality rate in the observational studies was $54.6 \%(184 / 337)$.

\subsubsection{CAPA Classification Criteria}

Three hundred and ninety-five CAPA cases were identified on the basis of the main classification criteria used by the authors of each study, and Table S3 summarises the classification criteria that we considered when we reclassified the CAPA cases using the patient-level data available in 35 studies (Table S2) on the basis of the clinical algorithms shown in Table 3. The newly proposed ECMM/ISHAM definition criteria identified a higher number of CAPA cases (236 probable, 79 possible) [106]; the IAPA classification of Verweij et al. [104] identified 211 cases, and that of Schauwvlieghe et al. [105] identified 206 cases. The new CAPA criteria of White et al. [30] identified 180 putative cases of CAPA, whereas the AspICU algorithm [103] identified only 49 putative cases but 163 patients with Aspergillus colonisation (it is the only clinical algorithm incorporating a "colonisation" category). The diagnostic criteria proposed by the EORTC/MSGE [107], which were 
originally designed and validated in the context of haematological patients, identified only 25 cases (Table 4 ).

\subsection{Candidemia and Other Yeast Fungemia}

The literature search identified 41 articles reporting cases of yeast fungemia during COVID-19 [2,14,15,21,29,30,36,44,45,51,54,60,108-136]; most of them were from Italy (9, $22 \%)$, followed by the USA $(6,14.6 \%)$ and Brazil $(4,9.8 \%)$.

\subsubsection{Case Reports and Case Series}

Nine case reports and seven case series were retrieved [108-123], together reporting 41 cases of candidemia (Table 4; detailed information about the individual studies is given in Table S4). The median time from ICU admission or intubation to the diagnosis of candidemia was 13.5 days (IQR 7.5-29.5), and more than $80 \%$ of the patients had an indwelling vascular catheter, received broad-spectrum antibiotics, and underwent mechanical ventilation before its onset. Eight patients received at least one dose of tocilizumab, seven were treated with baricitinib, and more than half received systemic corticosteroids for COVID-19 pneumonia.

In 18 episodes, Candida albicans was isolated (40.9\%), and 24 were due to other Candida species. In three patients from two studies, two Candida species were reported $[108,119]$. It is also worth noting that two patients were infected by Saccharomyces cerevisiae following treatment with a probiotic mixture for diarrhoea [118]. There were 11 cases of candidemia due to C. auris: two strains in the study of Allaw et al. and three in the study of De Almeida et al. were resistant to fluconazole and amphotericin B [112,114]; all of the six strains reported by Villanueva were resistant to amphotericin $B$ and three were resistant to fluconazole [119]. A secondary infectious focus was described in four patients (one had endophthalmitis, one retinitis, one endocarditis, and one had fungal costochondritis and spondylitis confirmed by bone biopsy histology and culture) $[109,113,123]$. Anti-fungal treatment was received by $87.8 \%$ of the patients, mainly echinocandins $(86 \%)$.

Twenty-three $(56.1 \%)$ of the patients died.

\subsubsection{Observational Studies}

Twenty-five observational studies reported 360 cases of candidemia, with an average incidence of $3.8 \%$ [2,14,15,21,29,30,36,44,45,51,54,60,124-136] (Table 5; detailed information about the individual studies is given in Table S5). More than $80 \%$ of the patients had classic risk factors (an in-dwelling vascular catheter and broad-spectrum antibiotics), but only $21.4 \%$ received total parenteral nutrition. C. albicans and C. glabrata accounted for more than a half of the cases, but it is worth noting that there were two reports of fungemia due to Trichosporon asahii and one case of Rhodotorula mucillaginosa fungemia $[133,135,137]$. The crude mortality rate was very high $(74.8 \%, 202 / 270)$. Six studies reported infections due to resistant Candida strains: Chowdahary et al. found that $30 \%$ of their C. auris isolates were multi-azole (fluconazole + voriconazole)-resistant [124], Posteraro et al. described one strain of C. glabrata resistant to echinocandins [127], Cataldo et al. found a strain of C. parapsilosis resistant to fluconazole [129], Magnasco et al. described four strains of C. auris resistant to azoles and amphotericin B [132], Kayaslaan reported 30\% of azoleresistant isolates, and Arasthefar found that two isolates were resistant to fluconazole and echinocandins $[15,133]$. Anti-fungal treatment was administered in 190 out of 253 cases (75\%), consisting mainly of echinocandins (82 patients, $43.2 \%$ ). 
Table 3. Comparison of the different CAPA diagnostic algorithms.

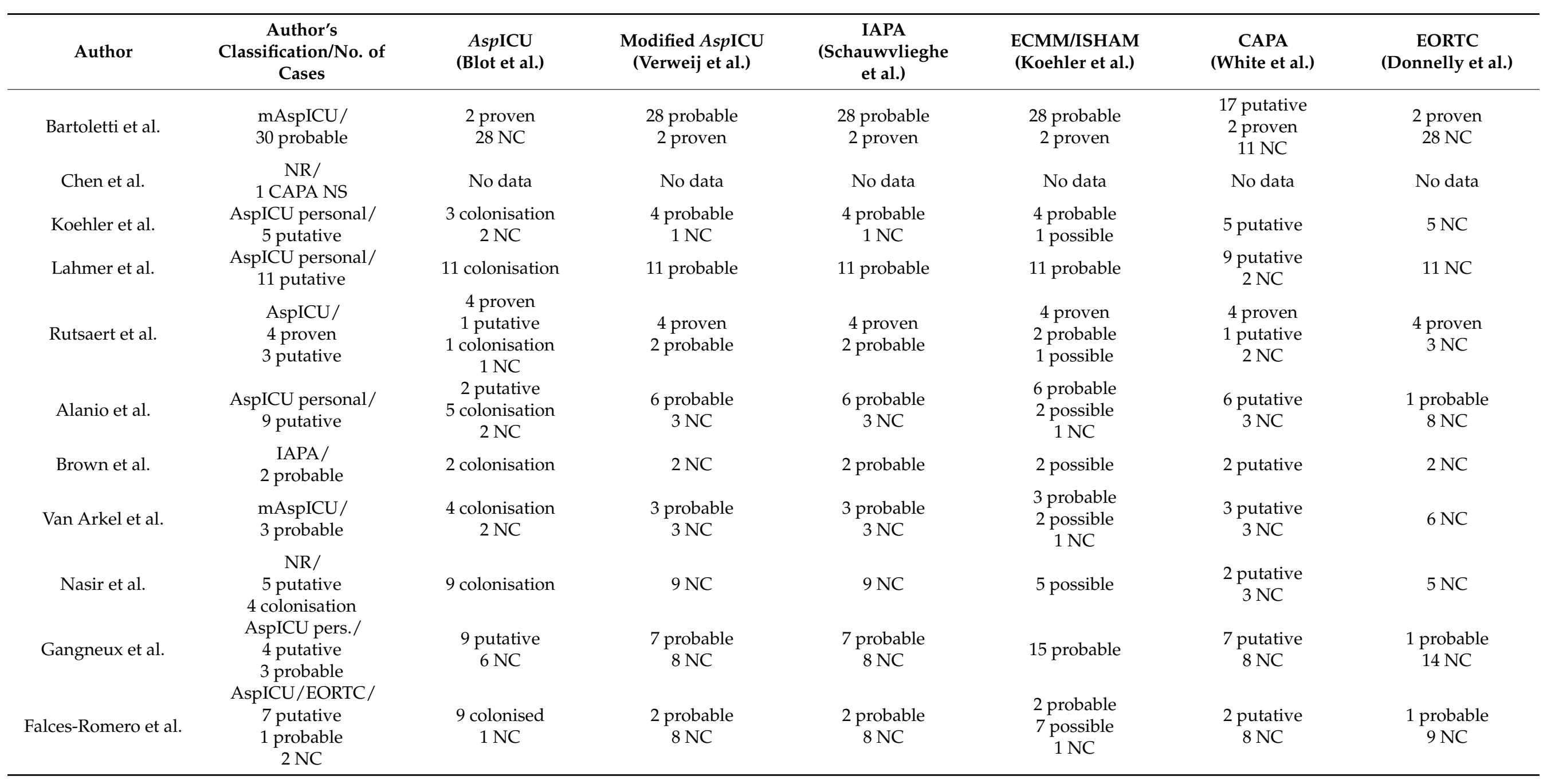


Table 3. Cont

\begin{tabular}{|c|c|c|c|c|c|c|c|}
\hline Author & $\begin{array}{c}\text { Author's } \\
\text { Classification/No. of } \\
\text { Cases }\end{array}$ & $\begin{array}{l}\text { AspICU } \\
\text { (Blot et al.) }\end{array}$ & $\begin{array}{l}\text { Modified AspICU } \\
\text { (Verweij et al.) }\end{array}$ & $\begin{array}{c}\text { IAPA } \\
\text { (Schauwvlieghe } \\
\text { et al.) }\end{array}$ & $\begin{array}{l}\text { ECMM/ISHAM } \\
\text { (Koehler et al.) }\end{array}$ & $\begin{array}{c}\text { CAPA } \\
\text { (White et al.) }\end{array}$ & $\begin{array}{c}\text { EORTC } \\
\text { (Donnelly et al.) }\end{array}$ \\
\hline Zhang et al. & $\begin{array}{c}\text { NR/ } \\
\text { 3 CAPA NS }\end{array}$ & No data & No data & No data & No data & No data & No data \\
\hline White et al. & $\begin{array}{l}\text { CAPA/ } \\
19 \text { putative }\end{array}$ & $\begin{array}{l}8 \text { putative } \\
3 \text { colonised } \\
14 \mathrm{NC}\end{array}$ & $\begin{array}{l}20 \text { probable } \\
5 \mathrm{NC}\end{array}$ & $\begin{array}{l}20 \text { probable } \\
5 \mathrm{NC}\end{array}$ & $\begin{array}{l}22 \text { probable } \\
3 \mathrm{NC}\end{array}$ & 19 putative & $\begin{array}{l}1 \text { probable } \\
24 \mathrm{NC}\end{array}$ \\
\hline Ichai et al. & $\begin{array}{c}\text { NR/ } \\
6 \text { probable/proven }\end{array}$ & No data & No data & No data & No data & No data & No data \\
\hline Sarrazyn et al. & $\begin{array}{l}\text { AspICU/ } \\
4 \text { putative }\end{array}$ & 4 colonisation & 4 probable & 4 probable & 4 probable & 4 putative & $4 \mathrm{NC}$ \\
\hline Dupont et al. & $\begin{array}{l}\text { AspICU pers./ } \\
19 \text { putative }\end{array}$ & $\begin{array}{c}2 \text { putative } \\
14 \text { colonised } \\
3 \mathrm{NC}\end{array}$ & $\begin{array}{l}12 \text { probable } \\
7 \mathrm{NC}\end{array}$ & $\begin{array}{l}11 \text { probable } \\
8 \mathrm{NC}\end{array}$ & $\begin{array}{l}11 \text { probable } \\
8 \text { possible }\end{array}$ & $\begin{array}{l}4 \text { putative } \\
15 \mathrm{NC}\end{array}$ & $19 \mathrm{NC}$ \\
\hline Mitaka et al. & $\begin{array}{l}\text { AspICU/ } \\
4 \text { putative }\end{array}$ & 4 putative & 4 probable & 4 probable & 4 probable & $\begin{array}{l}1 \text { putative } \\
3 \mathrm{NC}\end{array}$ & $4 \mathrm{NC}$ \\
\hline Borman et al. & $\begin{array}{l}\text { AspICU pers./ } \\
14 \text { probable } \\
1 \text { possible }\end{array}$ & $\begin{array}{l}1 \text { putative } \\
3 \text { colonised } \\
11 \mathrm{NC}\end{array}$ & $\begin{array}{c}8 \text { probable } \\
7 \mathrm{NC}\end{array}$ & $\begin{array}{l}8 \text { probable } \\
7 \mathrm{NC}\end{array}$ & $\begin{array}{l}9 \text { probable } \\
1 \text { possible } \\
5 \mathrm{NC}\end{array}$ & $\begin{array}{l}9 \text { putative } \\
6 \mathrm{NC}\end{array}$ & $15 \mathrm{NC}$ \\
\hline Rothe et al. & $\begin{array}{c}\text { NR/ } \\
9 \text { CAPA NS }\end{array}$ & No data & No data & No data & No data & No data & No data \\
\hline Wang et al. & $\begin{array}{l}\text { EORTC/ } \\
8 \text { possible }\end{array}$ & $\begin{array}{l}4 \text { colonisation } \\
4 \mathrm{NC}\end{array}$ & $\begin{array}{l}4 \text { probable } \\
4 \mathrm{NC}\end{array}$ & $\begin{array}{l}4 \text { probable } \\
4 \text { NC }\end{array}$ & $\begin{array}{l}4 \text { probable } \\
4 \text { NC }\end{array}$ & $\begin{array}{l}4 \text { putative } \\
4 \mathrm{NC}\end{array}$ & 8 possible \\
\hline Chauvet et al. & $\begin{array}{l}\text { Multiple/ } \\
5 \text { putative } \\
1 \text { possible }\end{array}$ & $\begin{array}{l}3 \text { putative } \\
1 \text { colonised } \\
2 \mathrm{NC}\end{array}$ & $\begin{array}{l}3 \text { probable } \\
3 \mathrm{NC}\end{array}$ & $\begin{array}{c}3 \text { probable } \\
3 \mathrm{NC}\end{array}$ & $\begin{array}{l}3 \text { probable } \\
2 \text { possible } \\
1 \mathrm{NC}\end{array}$ & $\begin{array}{l}2 \text { putative } \\
4 \mathrm{NC}\end{array}$ & $\begin{array}{l}1 \text { probable } \\
1 \text { possible } \\
4 \mathrm{NC}\end{array}$ \\
\hline Machado et al. & $\begin{array}{l}\text { AspICU/ } \\
8 \text { putative }\end{array}$ & 8 putative & $\begin{array}{l}6 \text { probable } \\
2 \mathrm{NC}\end{array}$ & $\begin{array}{l}6 \text { probable } \\
2 \mathrm{NC}\end{array}$ & $\begin{array}{l}6 \text { probable } \\
2 \text { possible }\end{array}$ & $\begin{array}{l}6 \text { putative } \\
2 \mathrm{NC}\end{array}$ & $\begin{array}{l}1 \text { probable } \\
5 \mathrm{NC}\end{array}$ \\
\hline Segrelles-Calvo et al. & $\begin{array}{l}\text { EORTC/ } \\
7 \text { probable }\end{array}$ & No data & No data & No data & No data & No data & No data \\
\hline Roman-Montes et al. & $\begin{array}{l}\text { IAPA/ } \\
14 \text { probable } \\
\text { Personal/ }\end{array}$ & $\begin{array}{l}10 \text { colonised } \\
4 \mathrm{NC}\end{array}$ & $\begin{array}{l}6 \text { probable } \\
8 \mathrm{NC}\end{array}$ & $\begin{array}{l}6 \text { probable } \\
8 \mathrm{NC}\end{array}$ & $\begin{array}{l}6 \text { probable } \\
8 \text { possible }\end{array}$ & $\begin{array}{l}13 \text { putative } \\
1 \mathrm{NC}\end{array}$ & $14 \mathrm{NC}$ \\
\hline Permpalung et al. & $\begin{array}{l}20 \text { probable } \\
19 \text { possible }\end{array}$ & No data & No data & No data & No data & No data & No data \\
\hline
\end{tabular}


Table 3. Cont

\begin{tabular}{|c|c|c|c|c|c|c|c|}
\hline Author & $\begin{array}{c}\text { Author's } \\
\text { Classification/No. of } \\
\text { Cases }\end{array}$ & $\begin{array}{c}\text { AspICU } \\
\text { (Blot et al.) }\end{array}$ & $\begin{array}{l}\text { Modified AspICU } \\
\text { (Verweij et al.) }\end{array}$ & $\begin{array}{c}\text { IAPA } \\
\text { (Schauwvlieghe } \\
\text { et al.) }\end{array}$ & $\begin{array}{l}\text { ECMM/ISHAM } \\
\text { (Koehler et al.) }\end{array}$ & $\begin{array}{c}\text { CAPA } \\
\text { (White et al.) }\end{array}$ & $\begin{array}{c}\text { EORTC } \\
\text { (Donnelly et al.) }\end{array}$ \\
\hline Delliere et al. & $\begin{array}{c}\text { mAspICU + EORTC/ } \\
21 \text { probable }\end{array}$ & $\begin{array}{c}2 \text { putative } \\
17 \text { colonised } \\
2 \mathrm{NC}\end{array}$ & $\begin{array}{l}19 \text { probable } \\
3 \mathrm{NC}\end{array}$ & $\begin{array}{l}16 \text { probable } \\
5 \mathrm{NC}\end{array}$ & $\begin{array}{l}16 \text { probable } \\
5 \text { possible }\end{array}$ & $\begin{array}{l}13 \text { putative } \\
8 \mathrm{NC}\end{array}$ & $\begin{array}{l}2 \text { probable } \\
19 \mathrm{NC}\end{array}$ \\
\hline Falcone et al. & $\begin{array}{c}\text { NR/ } \\
1 \text { CAPA NS }\end{array}$ & No data & No data & No data & No data & No data & No data \\
\hline Fekkar et al. & $\begin{array}{l}\text { EORTC/ } \\
6 \text { probable }\end{array}$ & $\begin{array}{l}4 \text { putative } \\
2 \text { colonised }\end{array}$ & $\begin{array}{l}4 \text { probable } \\
2 \text { NC }\end{array}$ & $\begin{array}{l}4 \text { probable } \\
2 \text { NC }\end{array}$ & $\begin{array}{l}5 \text { probable } \\
1 \text { possible }\end{array}$ & 6 putative & $\begin{array}{l}4 \text { probable } \\
2 \text { NC }\end{array}$ \\
\hline Gouzien et al. & $\begin{array}{l}\text { mAspICU/ } \\
2 \text { probable }\end{array}$ & $\begin{array}{l}1 \text { putative } \\
1 \text { colonised }\end{array}$ & 2 probable & 2 probable & 2 probable & $2 \mathrm{NC}$ & 2 probable \\
\hline Van Grootveld et al. & $\begin{array}{l}\text { ECMM/ } \\
11 \text { probable } \\
8 \mathrm{NC}\end{array}$ & $\begin{array}{c}1 \text { putative } \\
10 \text { colonised } \\
8 \mathrm{NC}\end{array}$ & $\begin{array}{l}10 \text { probable } \\
9 \mathrm{NC}\end{array}$ & $\begin{array}{l}10 \text { probable } \\
9 \mathrm{NC}\end{array}$ & $\begin{array}{l}11 \text { probable } \\
4 \text { possible } \\
4 \text { NC }\end{array}$ & $\begin{array}{l}10 \text { putative } \\
9 \mathrm{NC}\end{array}$ & $19 \mathrm{NC}$ \\
\hline Maes et al. & $\begin{array}{l}\text { IAPA/ } \\
3 \text { probable }\end{array}$ & $3 \mathrm{NC}$ & 3 probable & 3 probable & 3 probable & $3 \mathrm{NC}$ & $3 \mathrm{NC}$ \\
\hline Meijer et al. & $\begin{array}{l}\text { ECMM/ } \\
13 \text { probable }\end{array}$ & 13 colonised & $\begin{array}{c}8 \text { probable } \\
5 \mathrm{NC}\end{array}$ & $\begin{array}{c}8 \text { probable } \\
5 \mathrm{NC}\end{array}$ & $\begin{array}{l}8 \text { probable } \\
5 \text { possible }\end{array}$ & $\begin{array}{l}10 \text { putative } \\
3 \mathrm{NC}\end{array}$ & $13 \mathrm{NC}$ \\
\hline Obata et al. & $\begin{array}{c}\text { NR/ } \\
\text { 4 CAPA NS }\end{array}$ & No data & No data & No data & No data & No data & No data \\
\hline Razazi et al. & $\begin{array}{c}\text { mAspICU/IAPA } \\
7 \text { probable }\end{array}$ & $\begin{array}{l}2 \text { putative } \\
4 \text { colonised } \\
1 \mathrm{NC}\end{array}$ & $\begin{array}{l}6 \text { probable } \\
1 \mathrm{NC}\end{array}$ & $\begin{array}{l}6 \text { probable } \\
1 \mathrm{NC}\end{array}$ & $\begin{array}{l}6 \text { probable } \\
1 \mathrm{NC}\end{array}$ & $7 \mathrm{NC}$ & $7 \mathrm{NC}$ \\
\hline Ripa et al. & $\begin{array}{l}\text { AspICU personal/ } \\
11 \text { putative }\end{array}$ & No data & No data & No data & No data & No data & No data \\
\hline Pintado et al. & $\begin{array}{l}\text { ECMM/ } \\
16 \text { probable }\end{array}$ & No data & No data & No data & 16 probable & No data & No data \\
\hline Versych et al. & $\begin{array}{l}\text { IAPA/ } \\
2 \text { probable }\end{array}$ & 2 colonised & 2 probable & 2 probable & 2 probable & 2 putative & $2 \mathrm{NC}$ \\
\hline
\end{tabular}


Table 3. Cont

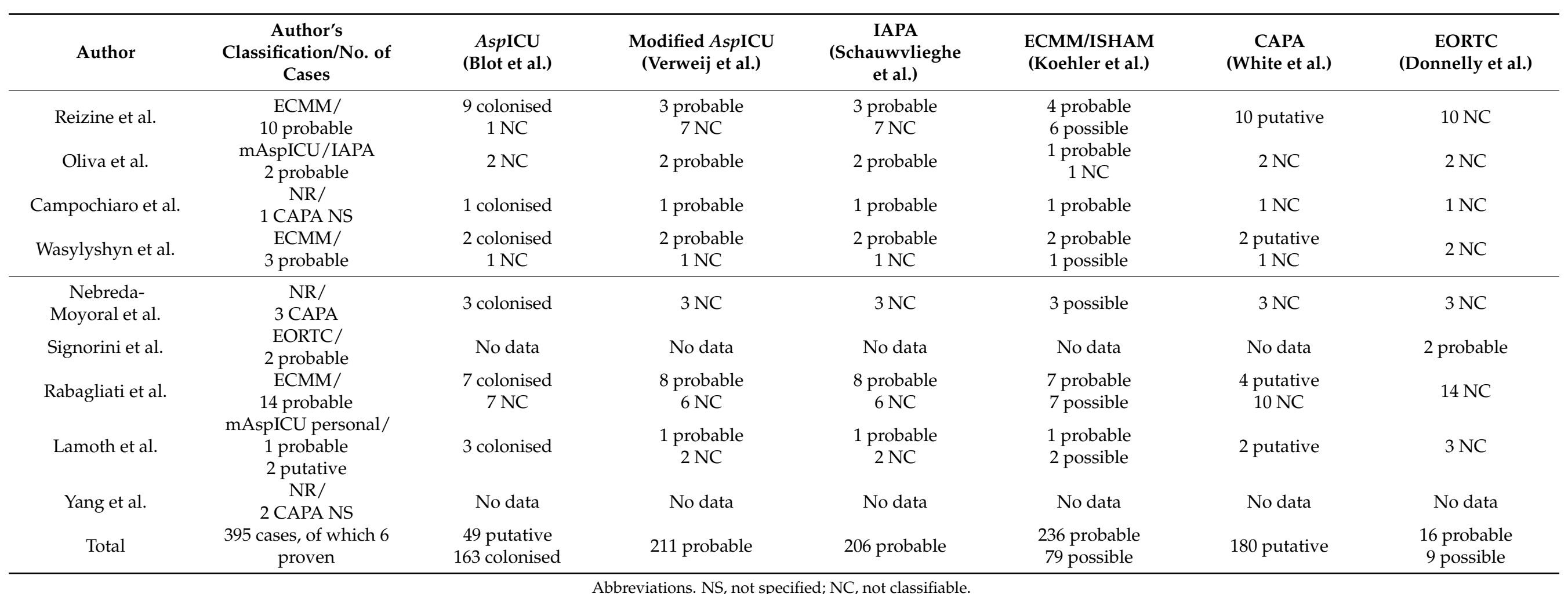


Table 4. Case reports and case series describing candidemia associated with COVID-19.

\begin{tabular}{|c|c|}
\hline Characteristics & No. $(\%)$ \\
\hline Candidemia cases & 41 \\
\hline Sex & Male: $32(78)$ \\
\hline \multirow[t]{3}{*}{ Median age (IQR) } & $64(54-72)$ \\
\hline & Diabetes mellitus: 27 (65.9) \\
\hline & Arterial hypertension: 24 (58.5) \\
\hline \multirow{4}{*}{ Main underlying diseases } & Cardiovascular disease: 9 (21.9) \\
\hline & Obesity: $9(21.9)$ \\
\hline & Chronic pulmonary disease: 4 (9.8) \\
\hline & Steroids: 27 (65.9) \\
\hline \multirow[t]{2}{*}{ COVID-19 treatments } & Tocilizumab: 8 (19.7) \\
\hline & Baricitinib: 7 (17.1) \\
\hline $\begin{array}{l}\text { Median number of days from ICU admission or TI } \\
\text { to candidemia (IQR) }\end{array}$ & $13.5(7.5-29.5)$ \\
\hline No. of patients with central venous catheters & $35(85.4)$ \\
\hline No. of patients on total parenteral nutrition & $5(12.8)$ \\
\hline No. of patients on antibiotic therapy & $34(82.9)$ \\
\hline \multirow[t]{3}{*}{ No. of patients undergoing mechanical ventilation } & $36(87.8)$ \\
\hline & C. albicans: 18 (40.9) \\
\hline & C. auris: $11(26.8)$ \\
\hline \multirow{5}{*}{ Candida species } & C. glabrata: 6 (14.6) \\
\hline & C. tropicalis: $4(9.8)$ \\
\hline & Other: 5 (12.2) \\
\hline & Total: 44 \\
\hline & Retinitis: 1 \\
\hline \multirow{5}{*}{ No. of patients with a secondary focus } & Endocarditis: 1 \\
\hline & Endophathalmitis: 1 \\
\hline & Osteomyelitis: 1 \\
\hline & $36(87.8)$ \\
\hline & Anidulafungin: 16 (44.4) \\
\hline \multirow{5}{*}{$\begin{array}{c}\text { No. patients receiving anti-fungal treatment } \\
\text { Anti-fungal agents }\end{array}$} & Caspofungin: $13(36.1)$ \\
\hline & Fluconazole: 12 (33.3) \\
\hline & Other azoles: 5 (13.9) \\
\hline & AMB: 4 (11.1) \\
\hline & Other: 3 (8.3) \\
\hline Number of deaths & $23(56.1)$ \\
\hline
\end{tabular}

Data are absolute numbers (percentages) unless otherwise specified. Abbreviations: ICU, intensive care unit; IQR, interquartile range; TI, tracheal intubation; AMB, amphotericin B.

Table 5. Observational studies reporting candidemia associated with COVID-19.

\begin{tabular}{cc}
\hline Characteristics & No. (\%) \\
\hline Sex & $360 / 9451(3.8)$ \\
& Male: $162(45.1)$ \\
No. of candidemia cases / total number of patients & Diabetes mellitus: $91(25.3)$ \\
Main underlying diseases & Arterial hypertension: $74(20.6)$ \\
& Cardiovascular disease: $60(16.7)$ \\
COVID-19 treatments & Chronic pulmonary disease: $37(10.3)$ \\
No. of patients with central venous catheters & Steroids: $156(43.4)$ \\
No. of patients on total parenteral nutrition & Tocilizumab: $69(19.2)$ \\
No. of patients on antibiotic therapy & $247 / 267(92.5)$ \\
No. of patients undergoing mechanical ventilation & $49 / 229(21.4)$ \\
& $172 / 180(95.6)$ \\
\end{tabular}


Table 5. Cont.

\begin{tabular}{cc}
\hline Characteristics & No. (\%) \\
\hline & C. albicans: $164(44.4)$ \\
Candida species & C. parapsilosis: $50(13.8)$ \\
& C. tropicalis: $31(8.5)$ \\
& C. auris: $20(5.5)$ \\
& C. dubliniensis: $4(1.1)$ \\
& Other: $43(11.8)$ \\
& Total: 363 \\
No. of patients receiving anti-fungal treatment & $190 / 253(75)$ \\
Anti-fungal agents & Fluconazole: $38(20)$ \\
& Anidulafungin: $37(19.4)$ \\
& Caspofungin: $25(13.2)$ \\
No. of deaths & Micafungin: $20(10.5)$ \\
& Fluconazole: $38(20)$ \\
\hline
\end{tabular}

Data are absolute numbers (percentage), unless otherwise specified. Abbreviations: ICU, intensive care unit; IQR, interquartile range; TI, tracheal intubation; $\mathrm{AMB}$, amphotericin $\mathrm{B}$.

\subsection{Mucormycosis}

The literature search identified 45 articles reporting cases of COVID-19-associated mucormycosis $[18,45,61,84,88,138-177]$. Most of the articles were from India $(19,42 \%)$ and the USA $(9,20 \%)$; eight articles were from European countries.

\subsubsection{Case Reports and Case Series}

Twenty-four case reports and nine case series [84,88,138-168] reported 59 cases of mucormycosis in patients with a median age of 51 years (IQR 42-62), 71.2\% of whom were males (Table 6; detailed information about the individual studies is given in Table S6). The most frequent co-morbidity was diabetes mellitus $(77.9 \%)$.

The majority of cases $(84.7 \%)$ were diagnosed during the clinical course of COVID-19, for which more half of the patients received systemic steroid treatment, and only $13.6 \%$ at least one dose of tocilizumab. The most frequent clinical presentations of mucormycosis (i9 cases each, 32.3\%) were rhino-orbital [144,145,151,154,159,161-164,166] and rhino-orbitocerebral [143,146-148,151-153,155,157,163,165], followed by 12 cases of pulmonary disease $(20.3 \%)[84,88,138,139,141,144,147,149,167]$. Autopsies of two cases revealed disseminated mucormycosis [144,158].

Histopathological examinations (HPEs) were carried out in all cases, $91.5 \%$ of which were positive; the diagnosis of the remaining five cases was supported by cultures of infected specimens (BAL, sputum, and purulent orbital material) [147,165]. Twenty-nine diagnoses of fungal rhinosinusitis were made on the basis of HPEs of nasal biopsies obtained during functional endoscopic sinus surgery (FESS); a further 10 diagnoses were based on HPEs of nasal material obtained by other means (discharges, scrapings, aspirates, or swabs). Definite diagnoses of pleuro-pulmonary mucormycosis were made after HPEs of BAL (three cases), a pulmonary biopsy (one case), pleural effusion (one case), a pleural biopsy (one case), induced sputum (one case), and BAL plus a pulmonary biopsy (one case) $[84,88,138,139,141,145,147,149,167]$.

Cultures were positive in $33 / 37$ patients $(89.2 \%)$. The most frequent finding was Rhizopus spp. (26 isolates), with the strain being identified in 13 cases: R. microsporus (five cases), R. arrhizus (seven cases), and R. azygosporus (three cases). The species was identified using molecular biology techniques on tissue biopsies (positive PCR) in two cases $[138,144]$. Anti-fungal treatment was administered to $93.1 \%$ of the patients, and $59.3 \%$ required surgical interventions (31 maxillo-facial debridements, two thoracic soft tissue debridements, one pleural decortication, and one pulmonary resection). 
Twenty-eight deaths were reported (50.8\%).

Table 6. Case reports and case series reporting mucomycosis associated with COVID-19.

\begin{tabular}{|c|c|}
\hline Characteristics & No. $(\%)$ \\
\hline Mucormycosis cases & 59 \\
\hline Sex & Males: 42 (71.2) \\
\hline \multirow{3}{*}{ Median age (IQR) } & $51(42-62)$ \\
\hline & Diabetes mellitus: 46 (77.9) \\
\hline & Arterial hypertension: 14 (23.7) \\
\hline \multirow[t]{3}{*}{ Main underlying diseases } & Cardiovascular disease: 6 (10.2) \\
\hline & Obesity: $5(8.4)$ \\
\hline & Chronic pulmonary disease: 2 (3.4) \\
\hline \multirow{2}{*}{ COVID-19 treatments } & Steroids: 33 (55.9) \\
\hline & Tocilizumab: 8 (13.6) \\
\hline \multirow{6}{*}{ Timing of occurrence of mucormycosis } & During COVID-19: 50 (84.7) \\
\hline & After COVID-19: 9 (15.3) \\
\hline & Rhino-orbital: 19 (32.2) \\
\hline & Rhino-orbital-cerebral: 19 (32.2) \\
\hline & Pulmonary: $12(20.3)$ \\
\hline & Rhino-sinusal: 3 (5.1) \\
\hline \multirow[t]{8}{*}{ Mucormycosis site } & Disseminated: 2 (3.4) \\
\hline & Soft tissues: 1 (1.7) \\
\hline & Muscolo-skeletal: 1 (1.7) \\
\hline & Gastric: $1(1.7)$ \\
\hline & Palatal: 1 (1.7) \\
\hline & $53 / 59(91.5)$ \\
\hline & Nasal biopsy: 29 (54.7) \\
\hline & Nasal material: 10 (18.9) \\
\hline \multirow{8}{*}{ Histopathological diagnosis, specimen } & Autopsy: 4 (7.5) \\
\hline & BAL: $4(7.5)$ \\
\hline & Lung biopsy: 2 (3.8) \\
\hline & Sputum: $1(1.9)$ \\
\hline & Other biopsies: 5 (9.4) \\
\hline & $33 / 37(89.2)$ \\
\hline & R. arrhizus: 7 \\
\hline & R. microsporus: 5 (+1 sample with only positive PCR) \\
\hline \multirow{6}{*}{ Positive culture species } & Lichtemia: 3 \\
\hline & R. azygosporus: 1 \\
\hline & Rhizopus/Mucor spp.: 13 \\
\hline & Species not specified: 4 \\
\hline & +1 case with a positive Mucorales PCR \\
\hline & $55 / 59(93.1)$ \\
\hline No. of patients receiving anti-fungal treatment & AMB: 53 (96.4) \\
\hline \multirow[t]{4}{*}{ Anti-fungal agents } & Azoles: 20 (36.4) \\
\hline & Echinocandins: 3 (5.5) \\
\hline & $35 / 59(59.3)$ \\
\hline & Maxillofacial surgery: 31 (88.6) \\
\hline \multirow[t]{3}{*}{ No. of patients undergoing surgery } & Lung resection: 1 (2.9) \\
\hline & Pleural decortication: 1 (2.9) \\
\hline & Soft tissue debridement: 1 (2.9) \\
\hline No. of deaths & $30(50.8)$ \\
\hline
\end{tabular}

Data are absolute numbers (percentage) unless otherwise specified. Abbreviations: IQR, interquartile range; AMB, amphotericin B; BAL, bronchial alveolar alavage. Nasal material: nasal samples other than biopsy (i.e., swabs, discharges, etc.).

\subsubsection{Observational Studies}

The literature search found 12 observational studies, in which 3126 cases of mucormycosis were described $[18,45,61,169-177]$, the average incidence of which was $8.6 \%$. As shown in Table 7 (detailed information about individual studies is given in Table S7), most of the patients were males $(70.6 \%)$, had diabetes mellitus $(76.1 \%)$, received systemic steroids 
for COVID-19 (73.8\%), and developed mucormycosis concomitantly with COVID-19. In the largest Indian study, the median time from the diagnosis of COVID-19 to the diagnosis of mucormycosis was 13 days [177]. Rhino-orbital and rhino-sinusal mucormycosis were the most frequent (respectively, $48.9 \%$ and $24.6 \%$ ); pulmonary involvement was reported in only 20 cases $(0.6 \%)$. The diagnosis was confirmed by means of histopathology in $1340 / 3062$ cases $(43.8 \%)$, whereas cultures revealed zygomycetes in only $23.6 \%$. The species was identified in 29 cases (5\%) and not reported 508 cases. In one case, the diagnosis was made on the basis of a positive Rhizopus /Mucor PCR in a respiratory sample and serum [45]. More than two-thirds of the patients received anti-fungal treatment $(75.6 \%)$, mainly amphotericin B (97.3\%). A surgical intervention was undertaken in 2352/3113 patients (68.3\%). All but two of the studies reported mortality data: the overall crude mortality rate was $16 \%$.

Table 7. Observational studies reporting mucormycosis associated with COVID-19.

\begin{tabular}{|c|c|}
\hline Characteristics & No. $(\%)$ \\
\hline No. of mucormycosis cases/total number of patients & $3126 / 36509(8.6)$ \\
\hline \multirow[t]{3}{*}{ Sex } & Male: 2206 (70.6) \\
\hline & Diabetes mellitus: 2379 (76.1) \\
\hline & Arterial hypertension: 731 (23.4) \\
\hline \multirow{3}{*}{ Main underlying diseases } & Cardiovascular disease: 38 (1.2) \\
\hline & Obesity: $4(0.1)$ \\
\hline & Chronic pulmonary disease: $27(0.9)$ \\
\hline \multirow{2}{*}{ COVID-19 treatments } & Steroids: 2307 (73.8) \\
\hline & Tocilizumab: 65 (2.1) \\
\hline \multirow{5}{*}{ Timing of occurrence } & During COVID-19: 231 \\
\hline & After COVID-19: 69 \\
\hline & Rhino-orbital: 1530 (48.9) \\
\hline & Rhino-sinusal: 769 (24.6) \\
\hline & Rhino-orbito-cerebral: 635 (20.3) \\
\hline \multirow[t]{4}{*}{ Mucormycosis site } & Pulmonary: $20(0.6)$ \\
\hline & Disseminated: $4(0.1)$ \\
\hline & Other sites: $4(0.1)$ \\
\hline & Site not specified: $5(0.2)$ \\
\hline \multirow{5}{*}{ Histopathological diagnosis } & $1340 / 3062(43.8)$ \\
\hline & $575 / 2437(23.6)$ \\
\hline & Mucorales not specified: 100 \\
\hline & Rhizopus spp.: 11 \\
\hline & R. arrhizus: 8 \\
\hline \multirow{8}{*}{ Positive culture Species } & Mucor spp.: 6 \\
\hline & Lichtemia spp.: 2 \\
\hline & R. stolonifer: 1 \\
\hline & R. microsporus: 1 \\
\hline & Species not specified: 508 \\
\hline & +1 case with positive Rhizopus/Mucor PCR on RS and serum \\
\hline & $2352 / 3113(75.6)$ \\
\hline & AMB: 2289 (97.3) \\
\hline No. of patients receiving anti-fungal treatment & Posaconazole: 799 (33.9) \\
\hline Anti-fungal agents & Isavuconazole: 54 (2.3) \\
\hline & Voriconazole: 2 (0.1) \\
\hline & Caspofungin: $2(0.1)$ \\
\hline No. of patients undergoing surgery & $1808 / 2646(68.3)$ \\
\hline No. of deaths & $405 / 2524(16)$ \\
\hline
\end{tabular}

Data are absolute numbers (percentage) unless otherwise specified. Abbreviations: AMB, amphotericin B. The two largest studies [176,177] report the median time from the diagnosis of COVID-19 to the diagnosis of COVID-associated mucormycosisbut not the frequency of patients with cuncurrent or post-COVID-19 infection. 


\subsection{Other Invasive Fungal Infections in COVID-19 Patients}

Twenty-five studies (20 case reports/case series and five observational studies) describe uncommon IFIs in COVID-19 patients [30,45,61,110,137,148,178-196] (Table 8). Most are from non-European countries (seven from South America, 28\%; six from the USA, 24\%; single reports from Canada, China, and Qatar).

Twenty cases of Pneumocystis jirovecii pneumonia (PCP) were reported, all of them diagnosed during the course of COVID-19; $30 \%$ of the patients were HIV-positive at the time of both diagnoses. More than half of the patients required mechanical ventilation. The diagnosis of PCP was established mainly on the basis of $P$. jirovecii PCR in respiratory samples $(80 \%)$; histopathological evidence was rare (one autoptic diagnosis, one direct examination of sputum) $[183,187]$. More than half of the patients received specific treatment $(65 \%)$, and eight deaths were reported [178-188].

Finally, there were five reports of cryptococcal infections (four cases of disseminated cryptococcosis, one case of cryptococcal meningitis) [110,137,189-191], four cases of histoplasmosis (three disseminated, one pulmonary) [192-195], one case of pulmonary infection due to Fusarium proliferatum [45], one case of COVID-19 and coccidioides co-infection [196], and one pulmonary Scedosporium infection confirmed by a positive BAL culture [61].

It is worth noting that 10 patients had a history of immunosuppression (one with chronic hemolytic anemia, one who had undergone a solid organ transplantation, and eight with AIDS) [178-181,186,188-190,192,194,195]. 
Table 8. Studies reporting rarer invasive fungal infections associated with COVID-19.

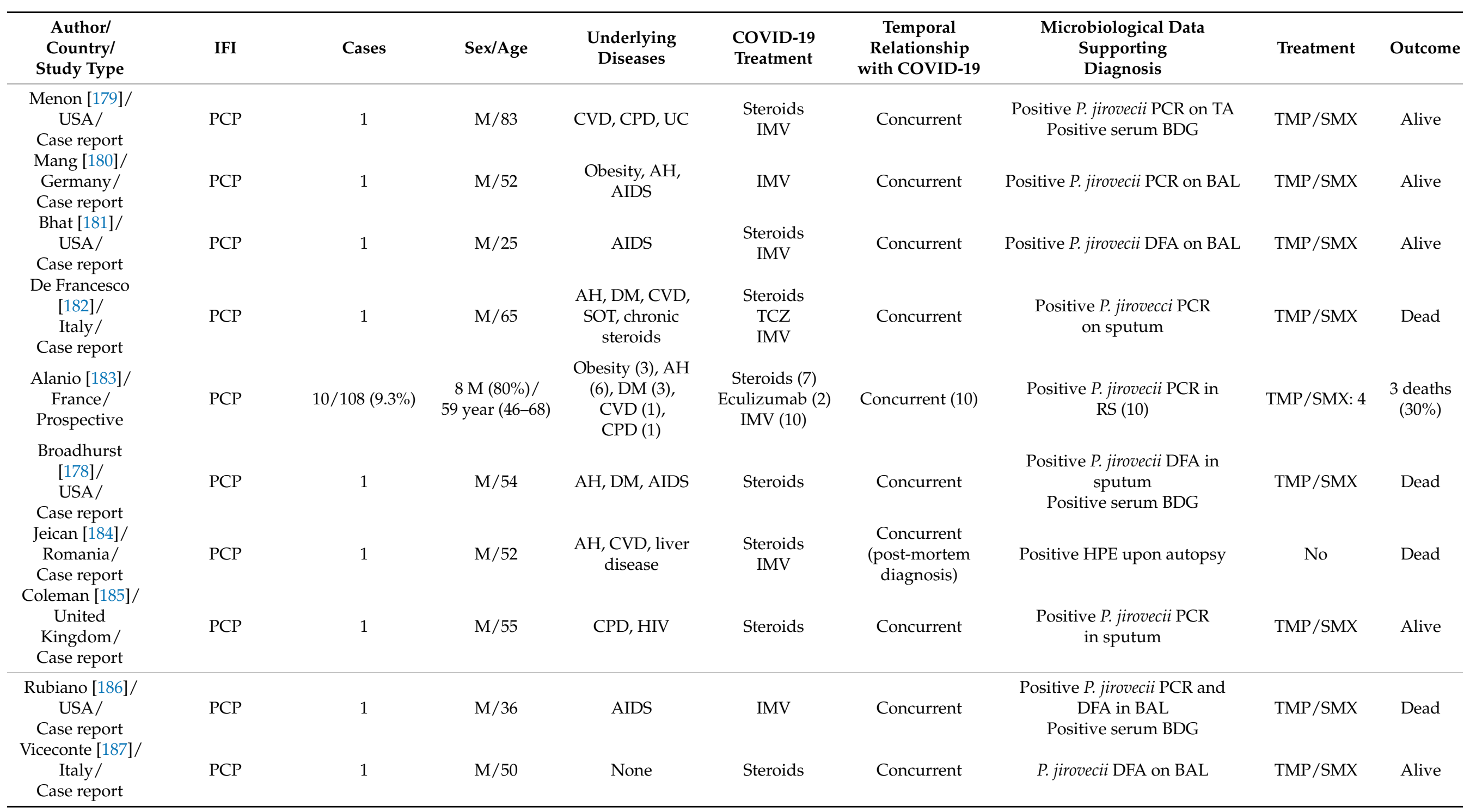


Table 8. Cont.

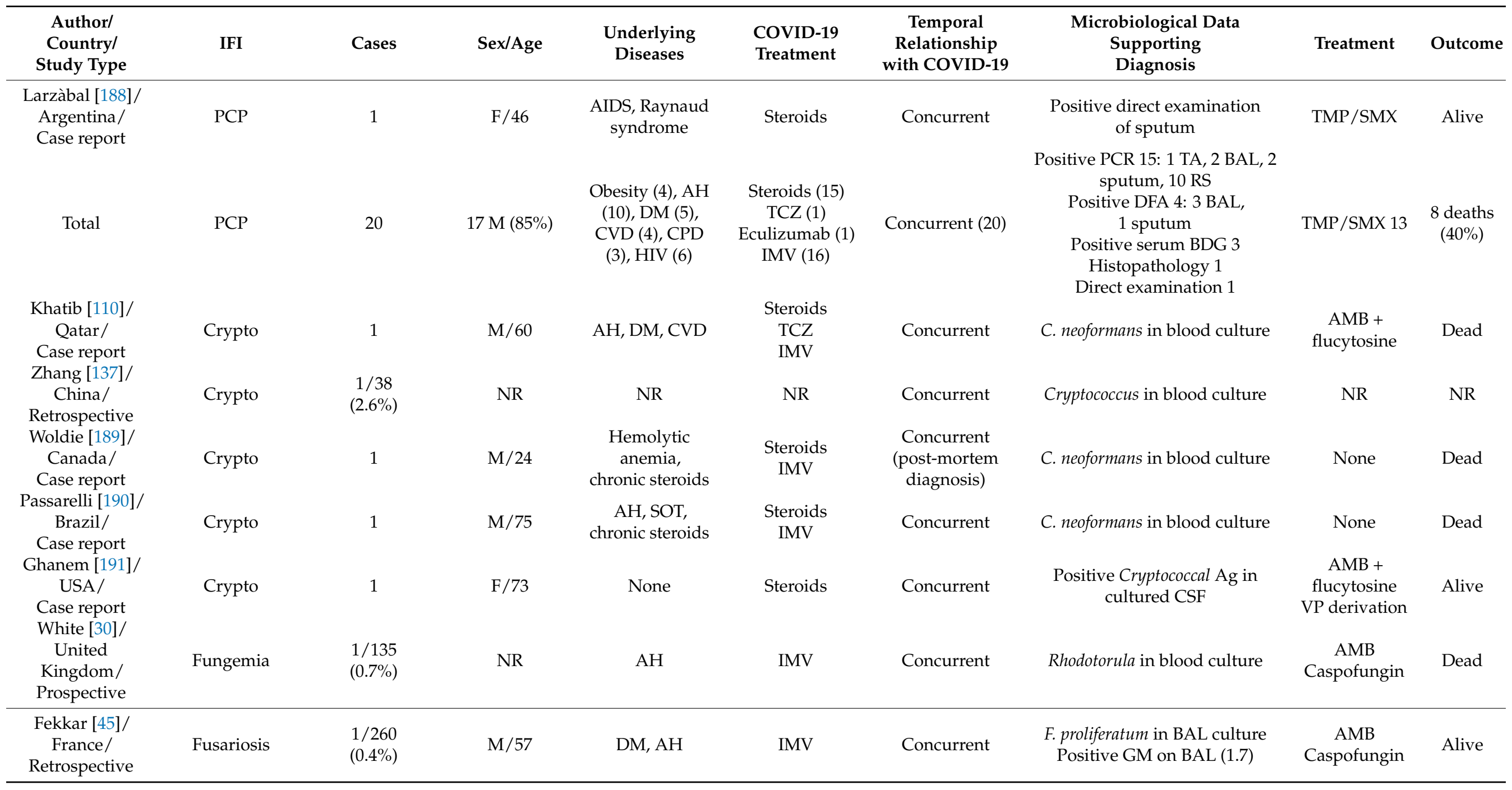


Table 8. Cont.

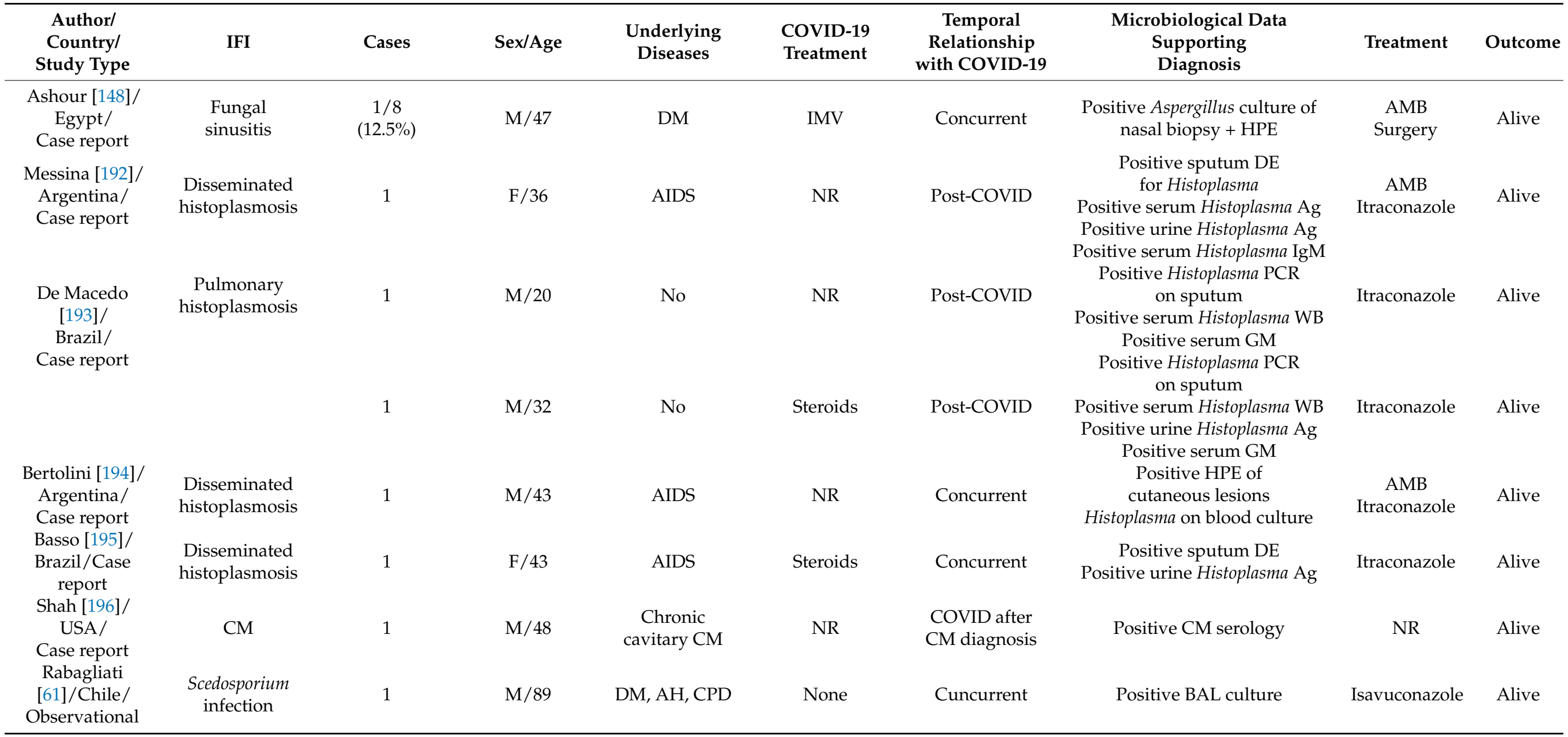

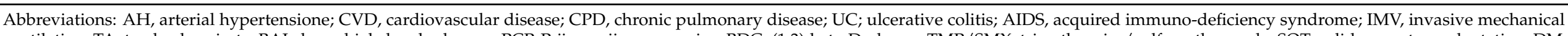

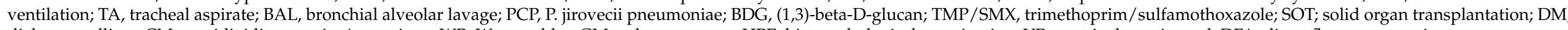
diabetes mellitus; CM, coccidioidiomycosis; Ag, antigen; WB, Western blot, GM, galactomannan; HPE, histopathological examination; VP, ventriculo-peritoneal, DFA, direct fluorescent antigen. 


\section{Discussion}

As expected, a number of cases of secondary bacterial and fungal infections have been reported since the emergence of COVID-19 and the publication of the first observational studies $[90,130,197]$; however, to the best of our knowledge, this is the only descriptive review of all of the types of IFI associated with COVID-19, the fungi involved, their clinical presentation and diagnostic difficulties, and their crude mortality rates. We identified 4099 cases of IFIs in 58,784 COVID-19 patients reported in 168 studies. CAPA and yeast fungemia were mainly reported among critically ill COVID-19 patients requiring ICU admission (in respectively $88 \%$ and $65 \%$ of the studies), whereas only $47 \%$ of the mucormycosis studies were carried out in an ICU.

Although it is currently unknown whether SARS-CoV-2 is an independent risk factor, patients with severe COVID-19 seem to be at risk of developing IPA. We identified a total of 478 cases of CAPA in 47 observational studies and 41 case reports/case series. Its average incidence was 3.9\%, but its incidence in the observational studies ranged from $0.1 \%$ [28] to $57 \%$ [34], a variability that is probably due to differences in the diagnostic strategies and clinical algorithms used by the authors.

It is difficult to diagnose IPA in ICU patients as all of the proposed diagnostic algorithms have major limitations (Table S3). The EORTC/MSG criteria do not really apply to COVID-19 patients because they often do not have any host risk factors and the CT criteria are infrequently observed in mechanically ventilated patients [107]. Among the patients we analysed, the EORTC/MSG criteria identified only 25 cases of CAPA (16 probable and 9 possible: $6.3 \%$ ). In a bid to overcome such limitations, Blot et al. validated the AspICU algorithm, which distinguishes putative IPA from Aspergillus colonisation (the other algorithms do not contemplate a "colonisation" category); however, although its diagnostic performance is better than that of the EORTC/MSG criteria, its main limitation is that it does not include indirect biomarkers of fungal infection (GM or BDG) [103], and it identified only 49 putative cases of CAPA (12.4\%).

The two case definitions of influenza-associated pulmonary aspergillosis (IAPA) in ICU patients proposed by Verweij and Schauwvlieghe allowed for a probable CAPA diagnosis in COVID-19 patients admitted to an ICU with pulmonary infiltrates and a positive BAL culture or BAL or serum GM $[104,105]$. These criteria are less stringent than the EORTC/MSG and AspICU criteria, but they may lead to an over-estimate of the incidence of CAPA and are less specific as patients with just a single positive GM test and chest X-ray infiltrates (frequent findings in critically ill COVID-19 patients) may be classified as having CAPA: applying these two criteria to all of the CAPA studies led to the identification of, respectively, $211(53.4 \%)$ and 206 cases $(52.2 \%)$, the second highest numbers of all of the classification criteria. Moreover, neither case definition includes the PCR testing of serum or respiratory sample or BDG, whereas it has been shown (at least in hematological patients) that the diagnostic performance of combining multiple biomarkers is better than using just one [198].

White et al. have proposed a new CAPA definition based on radiological and mycological criteria, which includes Aspergillus PCR testing and serum BDG, which in one study of ICU patients has shown to be more sensitive than serum GM in diagnosing aspergillosis [199]. However, although one biomarker may be diagnostically sufficient in the presence of a specific radiological feature, this new CAPA definition requires at least two positive mycology results to be sufficiently specific in the presence of non-specific chest radiology findings [30]. Nevertheless, in comparison with AspICU, it identified 131 more cases.

Finally, the consensus definition proposed by ECMM/ISHAM, which introduced the use of a lateral flow device or assay (LFD/LFA) as a mycological criterion and serial PCR testing of serum with the aim of increasing specificity, identified 315 CAPA cases (236 probable and 79 possible), the highest number of all of the classifications [106]. However, this was probably because it also includes other kinds of respiratory samples such as BAS or TA that inevitably decrease specificity despite their sensitivity, thus raising doubts about its ability to distinguish real cases of IPA from Aspergillus colonisation. For 
example, using the ECMM/ISHAM criteria, some of the CAPA cases reported by Alanio, Fekkar, and Rabagliati would be classified as probable CAPA on the basis of only one or two mycological criteria, whereas the authors state that these patients survived without any anti-fungal treatment, thus questioning the validity of the CAPA diagnosis [11,45,61], something that is also confirmed by applying the Verweij and Schauwvlieghe algorithms to the same patients.

The real incidence of CAPA is therefore difficult to estimate, regardless of which clinical algorithm is used. A systematic review by Chong et al., which only considered observational studies using well-defined diagnostic criteria, found an overall incidence of $13.5 \%$ (range 2.5-35\%) among COVID-19 patients [200], whereas Mitaka et al. found an incidence of $10.2 \%$ in ICU patients [201]. CAPA rates probably depend on patient selection and the study setting (mainly ICUs in the studies analysed here), and therefore it is difficult to make meaningful comparisons. For example, studies of ICU patients may suffer from "sample bias" (easier access to lower respiratory tract specimens, enhanced testing in screening programmes for fungal diseases), whereas, in other settings, the limited availability of diagnostic marker testing (PCR testing and serum BDG) and limited awareness of the disease may lead to a significant under-estimate.

Only $62 \%$ of the CAPA cases had a positive respiratory culture, and the specimen was BAL in $45 \%$ of cases, which means that a large proportion of the diagnoses were based on cultures of less informative respiratory specimens. Only a few studies provided data concerning direct microscopic examinations of respiratory samples, and a positive result (septate branching hyphae suggesting Aspergillus) was reported in only 24 cases (7.4\% of the positive cultures: $16 \mathrm{BAL}, 5 \mathrm{TA}, 1 \mathrm{BAS}$, and 2 unspecified respiratory specimens) $[24,33,35,43,47,52,54,65-67,71,76,86-89,92,96,102]$. According to Blot et al., positive direct examination of BAL is a crucial criterion for a diagnosis of putative IPA in ICU patients without host risk factors [103]. Given the paucity of direct microscopy data, the diagnostic yield of Blot's algorithm is low, although some authors considered COVID-19 a host risk factor and thus expanded its diagnostic capacity [22].

The diagnostic performance of the Aspergillus-specific PCR testing of respiratory samples was better than that of standard cultures $(78.3 \%$ considering case reports, case series, and observational studies together). Molecular biology techniques may provide added value when diagnosing IPA, even though most of the data come from adults with haematological malignancies [107], and usefulness of PCR testing in COVID-19 patients has not yet been demonstrated.

The diagnostic performance of serum GM (which ranged from $18 \%$ in the observational studies to $53.1 \%$ in the case reports; $22.4 \%$ overall) was much lower than that of BAL GM $(60 \%)$, thus confirming the poor sensitivity of the assay in non-neutropenic patients [202]. Moreover, a study by Farmakiotis et al. has shown that BAL GM has a high false positivity rate in patients without haematological malignancies [203]. In 10 studies, GM was tested in respiratory samples other than BAL (BAS, TA, or sputum) and had a positivity ratio of $61.5 \%$; however, in these specimens, GM and PCR testing have not been fully validated, sample collection is not targeted, and it is difficult to establish whether a positive culture corresponds to colonisation or infection and tissue invasion $[25,41,49,55]$. Serum BDG is apparently diagnostically better than serum GM and has a sensitivity of $36.7 \%(84 / 229)$, but this pan-fungal assay is not specific for aspergillosis.

Making a radiological diagnosis of IPA in COVID-19 patients is challenging for a number of reasons: (1) there numerous technical difficulties in obtaining CT images of patients admitted to an ICU, (2) the radiological features of COVID-19 can mask IPA, and (3) the low frequency of imaging suggesting IPA in mechanically ventilated patients [204]. As only $18.8 \%$ of the patients in observational studies and $33.3 \%$ of those described in case reports showed imaging features suggesting IPA, it seems that radiological criteria are of little help in diagnosing CAPA.

Finally, it must be remembered that only a few studies attempted to confirm the clinical diagnosis of CAPA by means of HPEs. Only 21 of our reported CAPA cases were 
histopathologically confirmed, mainly because invasive sampling is frequently unfeasible in COVID-19 patients, especially those who are if critically ill and admitted to an ICU. A recent systematic review of autopsy studies found that the prevalence of autopsy-proven invasive mould disease was only $2 \%$ (11/677 deaths, of which 8 were diagnosed as having CAPA [205]), a much lower value than the CAPA rates reported in some observational studies of ICU patients [11,24,30]. As HPE is the reference standard for diagnosing IFIs, the CAPA incidence rates in observational studies are probably over-estimated and the specificity of clinical algorithms is low. On the other hand, autopsies carried out at a single centre in Germany showed four out of eight patients in whom an IFIs was not clinically suspected actually had autoptic signs of an IFI that was considered the cause of death: two cases of CAPA and two of mucormycosis [206].

In brief, the real burden of CAPA has not yet been established as the currently available clinical tools are not sensitive or specific enough to detect it.

The average incidence of candidemia in the observational studies was $3.8 \%$, and the time between ICU admission and a diagnosis was 13.5 days. The latter is similar to the pooled mean duration of ICU admission before the onset of candidemia found by a recent meta-analysis (12.9 days) [207]. Nearly 30\% of the case report/case series came from the Middle East, whereas the highest number of observational studies of candidemia came from Italy (33\%) and the USA (16.7\%). A very high average crude mortality rate was observed in the observational studies (74.8\%), but it is worth noting that the ICU outcomes candidemia patients were worse than those observed CAPA patients even before the COVID-19 pandemic [208]. As recently pointed out by McCarty, it is difficult to consider COVID-19 patients hospitalised in an ICU and diagnosed with candidemia as a "truly unique patient population" because most of the patients had classic risk factors (i.e., an in-dwelling vascular catheter, antibiotic treatment, and mechanical ventilation) [209]. However, as $43 \%$ received steroids, $19.1 \%$ received tocilizumab, and $25.3 \%$ were affected by diabetes, it is possible that drug-induced or a metabolic-associated condition was responsible for an increased risk of infection.

The exact global burden of mucormycosis is not known because there is a lack of population-based studies, but its incidence is increasing, with India accounting for most of the cases worldwide [210,211]. It is worth noting that an unusually high number of mucormycosis cases in COVID-19 patients was reported during the second surge of the pandemic in India. Our search identified a total of 3185 cases distributed in 33 case reports/series and 12 observational studies, with an average incidence of $8.7 \%$; many of these came from India (12/33 case reports, 36\%, and 7/12 observational studies, 58.3\%). Rhino-orbital mucormycosis was the most frequently reported (48.6\% overall), and the strong association between COVID-19 and mucormycosis in the Indian population is probably due to a convergence of multiple concomitant risk factors: a higher baseline prevalence of the disease, favourable environmental factors (humidity, soil contamination, air pollution), a high and increasing prevalence of uncontrolled diabetes mellitus, and the widespread use of corticosteroids to treat COVID-19 (often beyond the indications of the guidelines) and possibly other immunosuppressive agents (i.e., anti-IL-6 agents) [176,212]. More than $76 \%$ of the candidemia patients considered in this review were affected by diabetes mellitus with poor glycaemic control, and almost $73 \%$ received systemic corticosteroids, which may worsen glycaemic control and presumably reduce host immune defences. The characteristics of the candidemia cases (disease localisation, etiologic agents, diagnostic methods, treatment, and outcomes) were similar to those with other IFI [211]. The observational studies indicate a low rate of histopathological diagnoses (43.8\%) and positive cultures $(23.6 \%)$, even though these are required for a proven diagnosis [213]. This is probably due to technical difficulties in obtaining diagnostic samples from COVID-19 patients because of safety concerns or clinical instability secondary to respiratory failure. Furthermore, Mucorales are fragile and, if the material taken from biopsies or other specimen is not managed carefully, a culture may become negative [213]. The treatment of mucormycosis is challenging and requires the prompt administration of anti-fungal agents 
and debulking surgery but, even after treatment, the average mortality rate associated with the disease is $40 \%$ [213]. Among the case reports/case series, maxillofacial surgery was reported in 35 cases (59.3\%); however, the outcome was not always favourable probably because of highly invasive disease [140,145,147-151,157,159,161,163]. More than one-third of the patients in the observational studies underwent surgical debridement. In the largest study of COVID-19-associated mucormycosis, a disease stage of $<3 b$ (orbital involvement without vision loss) was associated with a better outcome and, regardless of stage, surgery (paranasal sinus debridement and/or orbital exenteration) was associated with stable residual or regressive disease [177]. Together with infection control, the key elements of successful mucormycosis management suggested in the clinical guidelines are an early diagnosis, species identification, a combination of anti-fungal therapy and aggressive surgical resection/debridement, the optimisation of blood glucose levels, and the correct use of glucocorticoids for COVID-19 treatment (administration to hypoxic patients, and not exceeding the dose and treatment duration established by the guidelines) [213-216].

A few reports of other IFIs complicating COVID-19 (PCP, cryptococcosis, and histoplasmosis) have been published, but their burden is much less than that of CAPA, candidemia, or mucormycosis. However, physicians should be aware of the immunosuppressive potential of SARS-CoV-2 and consider these diagnoses in patients with suggestive signs and symptoms who experience an unexplained clinical worsening in COVID-19, even in the absence of severe baseline immunodepression $[1,19,182]$. Diagnosing PCP in COVID-19 patients is difficult and requires a high degree of clinical suspicion as they share some clinical features (signs and symptoms, pulmonary ground glass opacities in CT images, high levels of lactate dehydrogenase (LDH)). Positive Pneumocystis PCR tests of oropharyngeal wash samples or sputum probably over-estimate the real burden of the disease, and therefore treatment with cotrimoxazole may not always be indicated [183].

\section{Conclusions}

Increasing published evidence should warn physicians about the association between COVID-19 and IFIs. An increasing number of case reports and observational studies have shown that the clinical course of COVID-19 can be complicated by a variety of fungal super-infections with unfavourable outcomes. Although CAPA, CAM, and candidemia have received the most attention, physicians should remember that the invasive mycoses typically observed in highly immunodepressed patients can also be found in COVID-19 patients. One of the outstanding questions remains the true burden of fungal infections in COVID-19 patients, but the answer can only come from prospective studies that make an extra effort to obtain histopathological confirmation in order to reach a definite diagnosis.

Supplementary Materials: The following are available online at https:/ / www.mdpi.com/article/10 .3390/jof7110921/s1, Table S1: Case reports and case series describing CAPA. Table S2: Observational studies reporting CAPA. Table S3: Diagnostic algorithms used for CAPA. Table S4: Case reports/case series describing candidemia and yeast fungemia associated with COVID-19. Table S5: Observational studies reporting candidemia and yeast fungemia associated with COVID-19. Table S6: Case reports/case series describing mucormycosis associated with COVID-19. Table S7: Observational studies reporting mucormycosis associated with COVID-19.

Author Contributions: Conceptualisation: S.A.; literature search: G.C., S.A., A.G., A.R. and C.G.; data extraction: G.C., A.G. and S.A.; original draft preparation: G.C. manuscript review and editing: S.A., A.G., G.C., C.G. and A.R. All authors have read and agreed to the published version of the manuscript.

Funding: This research received no external funding.

Institutional Review Board Statement: Not applicable.

Informed Consent Statement: Not applicable.

Data Availability Statement: No new data were created or analysed in this study. Data sharing does not apply to this article. 
Conflicts of Interest: The authors declare they have no conflict of interest.

\section{References}

1. Cevik, M.; Kuppalli, K.; Kindrachuk, J.; Peiris, M. Virology, transmission, and pathogenesis of SARS-CoV-2. BMJ 2020, 371 , m3862. [CrossRef] [PubMed]

2. Ripa, M.; Galli, L.; Poli, A.; Oltolini, C.; Spagnuolo, V.; Mastrangelo, A.; Muccini, C.; Monti, G.; De Luca, G.; Landoni, G.; et al. Secondary infections in patients hospitalized with COVID-19: Incidence and predictive factors. Clin. Microbiol. Infect. 2021, 27, 451-457. [CrossRef] [PubMed]

3. Rawson, T.M.; Moore, L.; Zhu, N.; Ranganathan, N.; Skolimowska, K.; Gilchrist, M.; Satta, G.; Cooke, G.; Holmes, A. Bacterial and Fungal Coinfection in Individuals with Coronavirus: A Rapid Review to Support COVID-19 Antimicrobial Prescribing. Clin. Infect. Dis. 2020, 71, 2459-2468. [PubMed]

4. Diao, B.; Wang, C.; Tan, Y.; Chen, X.; Liu, Y.; Ning, L.; Chen, L.; Li, M.; Liu, Y.; Wang, G.; et al. Reduction and Functional Exhaustion of T Cells in Patients with Coronavirus Disease 2019 (COVID-19). Front. Immunol. 2020, 11, 827. [CrossRef]

5. Russell, C.D.; Fairfield, C.J.; Drake, T.M.; Turtle, L.; Seaton, R.A.; Wootton, D.G.; Sigfrid, L.; Harrison, E.M.; Docherty, A.B.; de Silva, T.I.; et al. Co-infections, secondary infections, and antimicrobial use in patients hospitalised with COVID-19 during the first pandemic wave from the ISARIC WHO CCP-UK study: A multicentre, prospective cohort study. Lancet Microbe 2021, 2, e354-e365. [CrossRef]

6. Fortún, J.; Martín-Dávila, P.; Moreno, S.; De Vicente, E.; Nuño, J.; Candelas, A.; Bárcena, R.; García, M. Risk factors for invasive aspergillosis in liver transplant recipients. Liver Transpl. 2002, 8, 1065-1070. [CrossRef] [PubMed]

7. van de Veerdonk, F.L.; Kolwijck, E.; Lestrade, P.P.; Hodiamont, C.J.; Rijnders, B.J.; van Paassen, J.; Haas, P.J.; Oliveira Dos Santos, C.; Kampinga, G.A.; Bergmans, D.C.; et al. Influenza-associated Aspergillosis in Critically Ill Patients. Am. J. Respir. Crit. Care Med. 2017, 196, 524-527. [CrossRef] [PubMed]

8. Bulpa, P.; Dive, A.; Sibille, Y. Invasive pulmonary aspergillosis in patients with chronic obstructive pulmonary disease. Eur. Respir. J. 2007, 30, 782-800. [CrossRef] [PubMed]

9. Gangneux, J.-P.; Bougnoux, M.-E.; Dannaoui, E.; Cornet, M.; Zahar, J.R. Invasive fungal diseases during COVID-19: We should be prepared. J. Mycol. Médicale 2020, 30, 100971. [CrossRef]

10. Gangneux, J.P.; Reizine, F.; Guegan, H.; Pinceaux, K.; Le Balch, P.; Prat, E.; Pelletier, R.; Belaz, S.; Le Souhaitier, M.; Le Tulzo, Y.; et al. Is the COVID-19 Pandemic a Good Time to Include Aspergillus Molecular Detection to Categorize Aspergillosis in ICU Patients? A Monocentric Experience. J. Fungi 2020, 6, 105. [CrossRef] [PubMed]

11. Alanio, A.; Dellière, S.; Fodil, S.; Bretagne, S.; Mégarbane, B. Prevalence of putative invasive pulmonary aspergillosis in critically ill patients with COVID-19. Lancet Respir. Med. 2020, 8, e48-e49. [CrossRef]

12. Chow, J.K.; Golan, Y.; Ruthazer, R.; Karchmer, A.W.; Carmeli, Y.; Lichtenberg, D.A.; Chawla, V.; Young, J.A.; Hadley, S. Risk factors for albicans and non-albicans candidaemia in the intensive care unit. Crit. Care Med. 2008, 36, 1993-1998. [CrossRef] [PubMed]

13. Hachem, R.; Hanna, H.; Kontoyiannis, D.; Jiang, Y.; Raad, I. The changing epidemiology of invasive candidiasis: Candida glabrata and Candida krusei as the leading causes of candidaemia in hematologic malignancy. Cancer 2008, 112, 2493-2499. [CrossRef] [PubMed]

14. Seagle, E.E.; Jackson, B.R.; Lockhart, S.R.; Georgacopoulos, O.; Nunnally, N.S.; Roland, J.; Barter, D.M.; Johnston, H.L.; Czaja, C.A.; Kayalioglu, H.; et al. The landscape of candidaemia during the COVID-19 pandemic. Clin. Infect. Dis. 2021, ciab562. [CrossRef]

15. Kayaaslan, B.; Eser, F.; Kaya Kalem, A.; Bilgic, Z.; Asilturk, D.; Hasanoglu, I.; Ayhan, M.; Tezer Tekce, Y.; Erdem, D.; Turan, S.; et al. Characteristics of Candidaemia in COVID-19 Patients; Increased Incidence, Earlier Occurrence, and Higher Mortality Rates Compared to Non-COVID-19 Patients. Mycoses 2021, 64, 1083-1091. [CrossRef]

16. Roden, M.M.; Zaoutis, T.E.; Buchanan, W.L.; Knudsen, T.A.; Sarkisova, T.A.; Schaufele, R.L.; Sein, M.; Sein, T.; Chiou, C.C.; Chu, J.H.; et al. Epidemiology and Outcome of Zygomycosis: A Review of 929 Reported Cases. Clin. Infect. Dis. 2005, 41, 634-653. [CrossRef] [PubMed]

17. Skiada, A.; Pagano, L.; Groll, A.; Zimmerli, S.; Dupont, B.; Lagrou, K.; Lass-Florl, C.; Bouza, E.; Klimko, N.; Gaustad, P.; et al. Zygomycosis in Europe: Analysis of 230 cases accrued by the registry of the European Confederation of Medical Mycology (ECMM) Working Group on Zygomycosis between 2005 and 2007. Clin. Microbiol. Infect. 2011, 17, 1859-1867. [CrossRef]

18. Bayram, N.; Ozsaygılı, C.; Sav, H.; Tekin, Y.; Gundogan, M.; Pangal, E.; Cicek, A.; Özcan, İ. Susceptibility of severe COVID-19 patients to rhino-orbital mucormycosis fungal infection in different clinical manifestations. Jpn. J. Ophthalmol. 2021, 65, 515-525. [CrossRef] [PubMed]

19. Qin, C.; Zhou, L.; Hu, Z.; Zhang, S.; Yang, S.; Tao, Y.; Xie, C.; Ma, K.; Shang, K.; Wang, W.; et al. Dysregulation of Immune Response in Patients With Coronavirus 2019 (COVID-19) in Wuhan, China. Clin. Infect. Dis. 2020, 71, 762-768. [CrossRef] [PubMed]

20. Bartoletti, M.; Pascale, R.; Cricca, M.; Rinaldi, M.; Maccaro, A.; Bussini, L.; Fornaro, G.; Tonetti, T.; Pizzilli, G.; Francalanci, E.; et al. Epidemiology of Invasive Pulmonary Aspergillosis Among Intubated Patients With COVID-19: A Prospective Study. Clin. Infect. Dis. 2020, ciaa1065. [CrossRef] [PubMed]

21. Chen, N.; Zhou, M.; Dong, X.; Qu, J.; Gong, F.; Han, Y.; Qiu, Y.; Wang, J.; Liu, Y.; Wei, Y.; et al. Epidemiological and clinical characteristics of 99 cases of 2019 novel coronavirus pneumonia in Wuhan, China: A descriptive study. Lancet 2020, 395, 507-513. [CrossRef] 
22. Koehler, P.; Cornely, O.A.; Böttiger, B.W.; Dusse, F.; Eichenauer, D.A.; Fuchs, F.; Hallek, M.; Jung, N.; Klein, F.; Persigehl, T.; et al. COVID-19 associated pulmonary aspergillosis. Mycoses 2020, 63, 528-534. [CrossRef] [PubMed]

23. Lahmer, T.; Kriescher, S.; Herner, A.; Rothe, K.; Spinner, C.D.; Schneider, J.; Mayer, U.; Neuenhahn, M.; Hoffmann, D.; Geisler, F.; et al. Invasive pulmonary aspergillosis in critically ill patients with severe COVID-19 pneumonia: Results from the prospective AspCOVID-19 study. PLoS ONE 2021, 16, e0238825. [CrossRef]

24. Rutsaert, L.; Steinfort, N.; Van Hunsel, T.; Bomans, P.; Naesens, R.; Mertes, H.; Dits, H.; Van Regenmortel, N. COVID-19-associated invasive pulmonary aspergillosis. Ann. Intensive Care 2020, 10, 71. [CrossRef] [PubMed]

25. Brown, L.K.; Ellis, J.; Gorton, R.; De, S.; Stone, N. Surveillance for COVID-19-associated pulmonary aspergillosis. Lancet Microbe 2020, 1, e152. [CrossRef]

26. van Arkel, A.; Rijpstra, T.A.; Belderbos, H.; van Wijngaarden, P.; Verweij, P.E.; Bentvelsen, R.G. COVID-19-associated Pulmonary Aspergillosis. Am. J. Respir. Crit. Care Med. 2020, 202, 132-135. [CrossRef] [PubMed]

27. Nasir, N.; Farooqi, J.; Mahmood, S.F.; Jabeen, K. COVID-19-associated pulmonary aspergillosis (CAPA) in patients admitted with severe COVID-19 pneumonia: An observational study from Pakistan. Mycoses 2020, 63, 766-770. [CrossRef] [PubMed]

28. Falces-Romero, I.; Ruiz-Bastián, M.; Díaz-Pollán, B.; Maseda, E.; García-Rodríguez, J.; SARS-CoV-2 Working Group. Isolation of Aspergillus spp. in respiratory samples of patients with COVID-19 in a Spanish Tertiary Care Hospital. Mycoses 2020, 63, 1144-1148. [CrossRef] [PubMed]

29. Zhang, J.J.; Dong, X.; Cao, Y.Y.; Yuan, Y.D.; Yang, Y.B.-; Yan, Y.Q.; Akdis, C.A.; Gao, Y.D. Clinical characteristics of 140 patients infected by SARS-CoV-2 in Wuhan, China. Allergy 2020, 75, 1730-1741. [CrossRef] [PubMed]

30. White, P.L.; Dhillon, R.; Cordey, A.; Hughes, H.; Faggian, F.; Soni, S.; Pandey, M.; Whitaker, H.; May, A.; Morgan, M.; et al. A National Strategy to Diagnose Coronavirus Disease 2019-Associated Invasive Fungal Disease in the Intensive Care Unit. Clin. Infect. Dis. 2020, 73, e1634-e1644. [CrossRef] [PubMed]

31. Ichai, P.; Saliba, F.; Baune, P.; Daoud, A.; Coilly, A.; Samuel, D. Impact of negative air pressure in ICU rooms on the risk of pulmonary aspergillosis in COVID-19 patients. Crit. Care 2020, 24, 538. [CrossRef] [PubMed]

32. Sarrazyn, C.; Dhaese, S.; Demey, B.; Vandecasteele, S.; Reynders, M.; Van Praet, J.T. Incidence, risk factors, timing and outcome of influenza versus Covid-19 associated putative invasive aspergillosis. Infect. Control Hosp. Epidemiol. 2020, 42, 1149-1150. [CrossRef] [PubMed]

33. Dupont, D.; Menotti, J.; Turc, J.; Miossec, C.; Wallet, F.; Richard, J.C.; Argaud, L.; Paulus, S.; Wallon, M.; Ader, F.; et al. Pulmonary aspergillosis in critically ill patients with Coronavirus Disease 2019 (COVID-19). Med. Mycol. 2021, 59, 110-114. [CrossRef] [PubMed]

34. Mitaka, H.; Perlman, D.C.; Javaid, W.; Salomon, N. Putative invasive pulmonary aspergillosis in critically ill patients with COVID-19: An observational study from New York City. Mycoses 2020, 63, 1368-1372. [CrossRef] [PubMed]

35. Borman, A.M.; Palmer, M.D.; Fraser, M.; Patterson, Z.; Mann, C.; Oliver, D.; Linton, C.J.; Gough, M.; Brown, P.; Dzietczyk, A.; et al. COVID-19-Associated Invasive Aspergillosis: Data from the UK National Mycology Reference Laboratory. J. Clin. Microbiol. 2020, 59, e02136-20. [CrossRef] [PubMed]

36. Rothe, K.; Feihl, S.; Schneider, J.; Wallnöfer, F.; Wurst, M.; Lukas, M.; Treiber, M.; Lahmer, T.; Heim, M.; Dommasch, M.; et al. Rates of bacterial co-infections and antimicrobial use in COVID-19 patients: A retrospective cohort study in light of antibiotic stewardship. Eur. J. Clin. Microbiol. Infect. Dis. 2021, 40, 859-869. [CrossRef] [PubMed]

37. Wang, D.; Hu, B.; Hu, C.; Zhu, F.; Liu, X.; Zhang, J.; Wang, B.; Xiang, H.; Cheng, Z.; Xiong, Y.; et al. Clinical Characteristics of 138 Hospitalized Patients With 2019 Novel Coronavirus-Infected Pneumonia in Wuhan, China. JAMA 2020, 323, 1061-1069. [CrossRef] [PubMed]

38. Chauvet, P.; Mallat, J.; Arumadura, C.; Vangrunderbeek, N.; Dupre, C.; Pauquet, P.; Orfi, A.; Granier, M.; Lemyze, M. Risk Factors for Invasive Pulmonary Aspergillosis in Critically Ill Patients with Coronavirus Disease 2019-Induced Acute Respiratory Distress Syndrome. Crit. Care Explor. 2020, 2, e0244. [CrossRef] [PubMed]

39. Machado, M.; Valerio, M.; Álvarez-Uría, A.; Olmedo, M.; Veintimilla, C.; Padilla, B.; De la Villa, S.; Guinea, J.; Escribano, P.; Ruiz-Serrano, M.J.; et al. Invasive pulmonary aspergillosis in the COVID-19 era: An expected new entity. Mycoses 2021, 64, 132-143. [CrossRef]

40. Segrelles-Calvo, G.; Araújo, G.; Llopis-Pastor, E.; Carrillo, J.; Hernández-Hernández, M.; Rey, L.; Melean, N.R.; Escribano, I.; Antón, E.; Zamarro, C.; et al. Prevalence of opportunistic invasive aspergillosis in COVID-19 patients with severe pneumonia. Mycoses 2021, 64, 144-151. [CrossRef] [PubMed]

41. Roman-Montes, C.M.; Martinez-Gamboa, A.; Diaz-Lomelí, P.; Cervantes-Sanchez, A.; Rangel-Cordero, A.; Sifuentes-Osornio, J.; Ponce-de-Leon, A.; Gonzalez-Lara, M.F. Accuracy of galactomannan testing on tracheal aspirates in COVID-19-associated pulmonary aspergillosis. Mycoses 2021, 64, 364-371. [CrossRef] [PubMed]

42. Permpalung, N.; Maertens, J.; Marr, K.A. Diagnostic dilemma in COVID-19-associated pulmonary aspergillosis. Lancet Infect. Dis. 2021, 21, 766-767. [CrossRef]

43. Dellière, S.; Dudoignon, E.; Fodil, S.; Voicu, S.; Collet, M.; Oillic, P.A.; Salmona, M.; Dépret, F.; Ghelfenstein-Ferreira, T.; Plaud, B.; et al. Risk factors associated with COVID-19-associated pulmonary aspergillosis in ICU patients: A French multicentric retrospective cohort. Clin. Microbiol. Infect. 2020, 27, 790.e1-790.e5. 
44. Falcone, M.; Tiseo, G.; Giordano, C.; Leonildi, A.; Menichini, M.; Vecchione, A.; Pistello, M.; Guarracino, F.; Ghiadoni, L.; Forfori, F.; et al. Predictors of hospital-acquired bacterial and fungal superinfections in COVID-19: A prospective observational study. J. Antimicrob. Chemother. 2021, 76, 1078-1084. [CrossRef] [PubMed]

45. Fekkar, A.; Lampros, A.; Mayaux, J.; Poignon, C.; Demeret, S.; Constantin, J.M.; Marcellin, A.G.; Monsel, A.; Luyt, C.E.; Blaize, M. Occurrence of Invasive Pulmonary Fungal Infections in Patients with Severe COVID-19 Admitted to the ICU. Am. J. Respir. Crit. Care Med. 2021, 203, 307-317. [CrossRef] [PubMed]

46. Gouzien, L.; Cocherie, T.; Eloy, O.; Legriel, S.; Bedos, J.P.; Simon, C.; Marque-Julliet, S.; Ferrè, A.; Bruneel, F. Invasive aspergillosis associated with Covid-19: A word of caution. Infect. Dis. Now 2021, 51, 383-386. [CrossRef] [PubMed]

47. van Grootveld, R.; van Paassen, J.; de Boer, M.; Claas, E.; Kuijper, E.J.; van der Beek, M.T.; LUMC-COVID-19 Research Group. Systematic screening for COVID-19 associated invasive aspergillosis in ICU patients by culture and PCR on tracheal aspirate. Mycoses 2021, 64, 641-650. [CrossRef] [PubMed]

48. Maes, M.; Higginson, E.; Pereira-Dias, J.; Curran, M.D.; Parmar, S.; Khokhar, F.; Cuchet-Lourenço, D.; Lux, J.; Sharma-Hajela, S.; Ravenhill, B.; et al. Ventilator-associated pneumonia in critically ill patients with COVID-19. Crit. Care 2021, 25, 25. [CrossRef]

49. Meijer, E.F.J; Dofferhoff, A.S.M.; Hoiting, O.; Meis, J.F. COVID-19-associated pulmonary aspergillosis: A prospective single-center dual case series. Mycoses 2021, 64, 457-464. [CrossRef]

50. Van Biesen, S.; Kwa, D.; Bosman, R.J.; Juffermans, N.P. Detection of Invasive Pulmonary Aspergillosis in COVID-19 with Non-directed Bronchoalveolar Lavage. Am. J. Respir. Crit. Care Med. 2020, 202, 1171-1173. [CrossRef] [PubMed]

51. Obata, R.; Maeda, T.; Rizk, D.; Kuno, T. Increased Secondary Infection in COVID-19 Patients Treated with Steroids in New York City. Jpn. J. Infect. Dis. 2021, 74, 307-315. [CrossRef] [PubMed]

52. Razazi, K.; Arrestier, R.; Haudebourg, A.F.; Benelli, B.; Carteaux, G.; Decousser, J.W.; Fourati, S.; Woerther, P.L.; Schlemmer, F.; Charles-Nelson, A.; et al. Risks of ventilator-associated pneumonia and invasive pulmonary aspergillosis in patients with viral acute respiratory distress syndrome related or not to Coronavirus 19 disease. Crit. Care. 2020, 24, 699, correction in 2021, 25, 118. [CrossRef] [PubMed]

53. Pintado, M.V.; Camiro-Zúñiga, A.; Soto, M.A.; Cuenca, D.; Mercado, M.; Crabtree-Ramirez, B.; ARMII Study Group. COVID-19associated invasive pulmonary aspergillosis in a tertiary care center in Mexico City. Med. Mycol. 2021, 59, 828-833. [CrossRef] [PubMed]

54. Versyck, M.; Zarrougui, W.; Lambiotte, F.; Elbeki, N.; Saint-Leger, P. Invasive pulmonary Aspergillosis in COVID-19 critically ill patients: Results of a French monocentric cohort. J. Med. Mycol. 2021, 31, 101122. [CrossRef] [PubMed]

55. Reizine, F.; Pinceaux, K.; Lederlin, M.; Autier, B.; Guegan, H.; Gacouin, A.; Luque-Paz, D.; Boglione-Kerrien, C.; Bacle, A.; Le Daré, B.; et al. Influenza- and COVID-19-Associated Pulmonary Aspergillosis: Are the Pictures Different? J. Fungi 2021, 7, 388. [CrossRef]

56. Oliva, A.; Ceccarelli, G.; Borrazzo, C.; Ridolfi, M.; D’Ettorre, G.; Alessandri, F.; Ruberto, F.; Pugliese, F.; Raponi, G.M.; Russo, A.; et al. Comparison of clinical features and outcomes in COVID-19 and influenza pneumonia patients requiring intensive care unit admission. Infection 2021, 49, 965-975. [CrossRef]

57. Campochiaro, C.; Della-Torre, E.; Cavalli, G.; De Luca, G.; Ripa, M.; Boffini, N.; Tomelleri, A.; Baldissera, E.; Rovere-Querini, P.; Ruggeri, A.; et al. Efficacy and safety of tocilizumab in severe COVID-19 patients: A single-centre retrospective cohort study. Eur. J. Intern. Med. 2020, 76, 43-49. [CrossRef]

58. Wasylyshyn, A.I.; Wasylyshyn, G.R.; Linder, K.A.; Miceli, M.H. COVID-19-Associated Pulmonary Aspergillosis at an Academic Medical Center in the Midwestern United States. Mycopathologia 2021, 186, 499-505. [CrossRef]

59. Nebreda-Mayoral, T.; Miguel-Gomez, M.A.; March-Rossellò, G.A.; Puente-Fuertes, L.; Cantòn-Benito, E.; Martinez-garc'a, A.M.; Munoz-Martin, A.B.; Orduna-Domingo, A. Infección bacteriana/fúngica en pacientes con COVID-19 ingresados en un hospital de tercer nivel de Castilla y León, Espana. Enferm. Infecc. Microbiol. Clin. 2020. [CrossRef]

60. Signorini, L.; Moioli, G.; Calza, S.; Van Hauwermeiren, E.; Lorenzotti, S.; Del Fabro, G.; Renisi, G.; Lanza, P.; Saccani, B.; Zambolin, G.; et al. Epidemiological and Clinical Characterization of Superinfections in Critically Ill Coronavirus Disease 2019 Patients. Crit. Care Explor. 2021, 3, e0430. [CrossRef]

61. Rabagliati, R.; Rodríguez, N.; Núñez, C.; Huete, A.; Bravo, S.; Garcia, P. COVID-19-Associated Mold Infection in Critically Ill Patients, Chile. Emerg. Infect. Dis. 2021, 27, 1454-1456. [CrossRef]

62. Lamoth, F.; Glampedakis, E.; Boillat-Blanco, N.; Oddo, M.; Pagani, J.L. Incidence of invasive pulmonary Aspergillosis among critically ill COVID-19 patients. Clin. Microbiol. Infect. 2020, 26, 1706-1708. [CrossRef]

63. Yang, X.; Yu, Y.; Xu, J.; Shu, H.; Xia, J.; Liu, H.; Wu, Y.; Zhang, L.; Yu, Z.; Fang, M.; et al. Clinical course and outcomes of critically ill patients with SARS-CoV-2 pneumonia in Wuhan, China: A single-centered, retrospective, observational study. Lancet Respir. Med. 2020, 8, 475-481. [CrossRef]

64. Imoto, W.; Himura, H.; Matsuo, K.; Kawata, S.; Kiritoshi, A.; Deguchi, R.; Miyashita, M.; Kaga, S.; Noda, T.; Yamamoto, K.; et al COVID-19-associated pulmonary aspergillosis in a Japanese man: A case report. J Infect Chemother. 2021, 27, 911-914. [CrossRef] [PubMed]

65. Trovato, L.; Calvo, M.; Migliorisi, G.; Astuto, M.; Oliveri, F.; Oliveri, S. Fatal VAP-related pulmonary Aspergillosis by Aspergillus niger in a positive COVID-19 patient. Respir. Med. Case Rep. 2021, 32, 101367. [PubMed] 
66. Benedetti, M.F.; Alava, K.H.; Sagardia, J.; Cadena, R.C.; Laplume, D.; Capece, P.; Posse, G.; Nusblat, A.D.; Cuestas, M.L. COVID-19 associated pulmonary Aspergillosis in ICU patients: Report of five cases from Argentina. Med. Mycol. Case Rep. 2021, $31,24-28$. [CrossRef] [PubMed]

67. Iwanaga, Y.; Kawanami, T.; Yamasaki, K.; Sakakibara, H.; Ikushima, I.; Ikegami, H.; Tahara, M.; Akata, K.; Mukae, H.; Yatera, K. A fatal case of COVID-19-associated invasive pulmonary aspergillosis. J. Infect. Chemother. 2021, 27, 1102-1107. [CrossRef]

68. Lahmer, T.; Rasch, S.; Spinner, C.; Geisler, F.; Schmid, R.M.; Huber, W. Invasive pulmonary aspergillosis in severe coronavirus disease 2019 pneumonia. Clin. Microbiol. Infect. 2020, 26, 1428-1429. [CrossRef]

69. Antinori, S.; Rech, R.; Galimberti, L.; Castelli, A.; Angeli, E.; Fossali, T.; Bernasconi, D.; Covizzi, A.; Bonazzetti, C.; Torre, A.; et al. Invasive pulmonary aspergillosis complicating SARS-CoV-2 pneumonia: A diagnostic challenge. Travel Med. Infect. Dis. 2020, 38, 101752. [CrossRef] [PubMed]

70. Prattes, J.; Valentin, T.; Hoenigl, M.; Talakic, E.; Reisinger, A.C.; Eller, P. Invasive pulmonary Aspergillosis complicating COVID-19 in the ICU-A case report. Med. Mycol. Case Rep. 2021, 31, 2-5. [CrossRef] [PubMed]

71. Blaize, M.; Mayaux, J.; Nabet, C.; Lampros, A.; Marcelin, A.G.; Thellier, M.; Piarroux, R.; Demoule, A.; Fekkar, A. Fatal Invasive Aspergillosis and Coronavirus Disease in an Immunocompetent Patient. Emerg. Infect. Dis. 2020, 26, 1636-1637. [CrossRef] [PubMed]

72. Santana, M.F.; Pivoto, G.; Alexandre, M.A.A.; Baía-da-Silva, D.C.; da Silva Borba, M.G.; Val, F.A.; Brito-Sousa, J.D.; Melo, G.C.; Monteiro, W.M.; Souza, J.V.B.; et al. Confirmed Invasive Pulmonary Aspergillosis and COVID-19: The value of postmortem findings to support antemortem management. Rev. Soc. Bras. Med. Trop. 2020, 53, e20200401. [CrossRef]

73. Helleberg, M.; Steensen, M.; Arendrup, M.C. Invasive aspergillosis in patients with severe COVID-19 pneumonia. Clin. Microbiol. Infect. 2021, 27, 147-148. [CrossRef] [PubMed]

74. Bruno, G.; Fabrizio, C.; Buccoliero, G.B. COVID-19-associated pulmonary aspergillosis: Adding insult to injury. Lancet Microbe 2020, 1, e106. [CrossRef]

75. Mohamed, A.; Hassan, T.; Trzos-Grzybowska, M.; Thomas, J.; Quinn, A.; O’Sullivan, M.; Griffin, A.; Rogers, T.R.; Talento, A.F. Multi-triazole-resistant Aspergillus fumigatus and SARS-CoV-2 co-infection: A lethal combination. Med. Mycol. Case Rep. 2021, 31, 11-14. [CrossRef] [PubMed]

76. Ghelfenstein-Ferreira, T.; Saade, A.; Alanio, A.; Bretagne, S.; de Castro, R.A.; Hamane, S.; Azoulay, E.; Bredin, S.; Dellieère, S. Recovery of a triazole-resistant Aspergillus fumigatus in respiratory specimen of COVID-19 patient in ICU-A case report. Med. Mycol. Case Rep. 2021, 31, 15-18. [CrossRef]

77. Fernandez, N.B.; Caceres, D.H.; Beer, K.D.; Irrazabal, C.; Delgado, G.; Farias, L.; Chiller, T.M.; Verweij, P.E.; Stecher, D. Ventilatorassociated pneumonia involving Aspergillus flavus in a patient with coronavirus disease 2019 (COVID-19) from Argentina. Med. Mycol. Case Rep. 2021, 31, 19-23. [CrossRef]

78. Schein, F.; Munoz-Pons, H.; Mahinc, C.; Grange, R.; Cathébras, P.; Flori, P. Fatal aspergillosis complicating severe SARS-CoV-2 infection: A case report. J. Mycol. Médicale 2020, 30, 101039. [CrossRef] [PubMed]

79. Abdalla, S.; Almaslamani, M.A.; Hashim, S.M.; Ibrahim, A.S.; Omrani, A.S. Fatal Coronavirus Disease 2019-associated Pulmonary Aspergillosis: A Report of Two Cases and Review of the Literature. IDCases 2020, 22, e00935. [CrossRef] [PubMed]

80. Patti, R.K.; Dalsania, N.R.; Somal, N.; Sinha, A.; Mehta, S.; Ghitan, M.; Seneviratne, C.; Kupfer, Y. Subacute Aspergillosis “Fungal Balls" Complicating COVID-19. J. Investig. Med. High Impact. Case Rep. 2020, 8. [CrossRef]

81. Marr, K.A.; Platt, A.; Tornheim, J.A.; Zhang, S.X.; Datta, K.; Cardozo, C.; Garcia-Vidal, C. Aspergillosis Complicating Severe Coronavirus Disease. Emerg. Infect. Dis. 2021, 27, 18-25. [CrossRef]

82. Trujillo, H.; Fernández-Ruiz, M.; Gutiérrez, E.; Sevillano, Á.; Caravaca-Fontán, F.; Morales, E.; Lòpez-Medrano, F.; Aguado, J.M.; Praga, M.; Andrès, A. Invasive pulmonary aspergillosis associated with COVID-19 in a kidney transplant recipient. Transpl. Infect. Dis. 2021, 23, e13501. [CrossRef] [PubMed]

83. Shadrach, B.J.; Goel, R.; Deokar, K.; Jain, A. Invasive pulmonary aspergillosis in a COVID-19 recovered patient: Unravelling an infective sequalae of the SARS-CoV-2 virus. Monaldi Arch. Chest Dis. 2021, 91. [CrossRef]

84. Bellanger, A.P.; Navellou, J.C.; Lepiller, Q.; Brion, A.; Brunel, A.S.; Millon, L.; Berceanu, A. Mixed mold infection with Aspergillus fumigatus and Rhizopus microsporus in a Severe Acute Respiratory syndrome Coronavirus 2 (SARS-CoV-2) patient. Infect. Dis. Now 2021, 51, 633-635. [PubMed]

85. Witting, C.; Quaggin-Smith, J.; Mylvaganam, R.; Peigh, G.; Angarone, M.; Flaherty, J.D. Invasive pulmonary aspergillosis after treatment with tocilizumab in a patient with COVID-19 ARDS: A case report. Diagn. Microbiol. Infect. Dis. 2021, $99,115272$. [CrossRef] [PubMed]

86. Haglund, A.; Christensen, S.; Kristensen, L.; Gertsen, J.B.; Buus, L.; Lausch, K.R. Invasive pulmonary aspergillosis and hyperthermia in an immunocompetent patient with COVID-19. Med. Mycol. Case Rep. 2021, 31, 29-31. [CrossRef] [PubMed]

87. Hakamifard, A.; Hashemi, M.; Fakhim, H.; Aboutalebian, S.; Hajiahmadi, S.; Mohammadi, R. Fatal disseminated aspergillosis in an immunocompetent patient with COVID-19 due to Aspergillus ochraceus. J. Med. Mycol. 2021, 31, 101124. [CrossRef] [PubMed]

88. Johnson, A.K.; Ghazarian, Z.; Cendrowski, K.D.; Persichino, J.G. Pulmonary aspergillosis and mucormycosis in a patient with COVID-19. Med. Mycol. Case Rep. 2021, 32, 64-67. [CrossRef] [PubMed]

89. Kakamad, F.H.; Mahmood, S.O.; Rahim, H.M.; Abdulla, B.A.; Abdullah, H.O.; Othman, S.; Mohammed, S.H.; Kakamad, S.H.; Mustafa, S.M.; Salih, A.M. Post covid-19 invasive pulmonary aspergillosis: A case report. Int. J. Surg. Case Rep. 2021, 82, 105865. [CrossRef] 
90. Lescure, F.X.; Bouadma, L.; Nguyen, D.; Parisey, M.; Wicky, P.H.; Behillil, S.; Gaymard, A.; Bouscambert-Duchamp, M.; Donati, F.; Le Hingrat, Q.; et al. Clinical and virological data of the first cases of COVID-19 in Europe: A case series. Lancet Infect. Dis. 2020, 20, 697-706. [CrossRef]

91. Nasrullah, A.; Javed, A.; Malik, K. Coronavirus Disease-Associated Pulmonary Aspergillosis: A Devastating Complication of COVID-19. Cureus 2021, 13, e13004. [PubMed]

92. Salehi, M.; Khajavirad, N.; Seifi, A.; Salahshour, F.; Jahanbin, B.; Kazemizadeh, H.; Hashemi, S.J.; Manshadi, S.A.D.; Kord, M.; Verweij, P.E.; et al. Proven Aspergillus flavus pulmonary aspergillosis in a COVID-19 patient: A case report and review of the literature. Mycoses 2021, 64, 809-816. [CrossRef] [PubMed]

93. Sasoni, N.; Rodriguez Müller, M.; Posse, G.; González, J.; Leonardelli, F.; Garcia-Effron, G. SARS-CoV-2 and Aspergillus section Fumigati coinfection in an immunocompetent patient treated with corticosteroids. Rev. Iberoam Micol. 2021, 38, 16-18. [CrossRef]

94. Sharma, A.; Hofmeyr, A.; Bansal, A.; Thakkar, D.; Lam, L.; Harrington, Z.; Bhonagiri, D. COVID-19 associated pulmonary aspergillosis (CAPA): An Australian case report. Med. Mycol. Case Rep. 2021, 31, 6-10. [CrossRef] [PubMed]

95. van Someren Gréve, F.; du Long, R.; Talwar, R.; Beurskens, C.J.P.; Voerman, H.J.; van Dijk, K. Proven Fatal Invasive Aspergillosis in a Patient with COVID-19 and Staphylococcus aureus Pneumonia. J. Fungi 2021, 7, 230. [CrossRef]

96. Abolghasemi, S.; Hakamifard, A.; Sharifynia, S.; Pourabdollah Toutkaboni, M.; Azhdari Tehrani, H. Fatal invasive pulmonary aspergillosis in an immunocompetent patient with COVID-19 due to Aspergillus terreus: A case study. Clin. Case Rep. 2021, 9, 2414-2418. [CrossRef] [PubMed]

97. Steenwyk, J.L.; Mead, M.E.; de Castro, P.A.; Valero, C.; Damasio, A.; dos Santos, R.A.C.; Labella, A.L.; Li, Y.; Knowles, S.L.; Raja, H.A.; et al. Genomic and phenotypic analysis of COVID-19-associated pulmonary aspergillosis isolates of Aspergillus fumigatus. Microbiol Spectr. 2021, 9, e00010-21. [CrossRef] [PubMed]

98. Flikweert, A.W.; Grootenboers, M.; Yick, D.; du Mée, A.; van der Meer, N.; Rettig, T.; Kant, M. Late histopathologic characteristics of critically ill COVID-19 patients: Different phenotypes without evidence of invasive aspergillosis, a case series. J. Crit. Care. 2020, 59, 149-155. [CrossRef] [PubMed]

99. Clemente, M.G.; Valverde, T.H.; Leizaola-Irigoyen, O.; Rodríguez, A.I.E.; Guillén, M.A.; Asensio, M.T.; Carus, E.G.; Garcìa, T.P. ¿ Puede ser la infección por SARS-CoV-2 un factor de riesgo de aspergilosis pulmonar? Arch. Bronconeumol. 2021, 57, 72-73. [CrossRef] [PubMed]

100. Nasri, E.; Shoaei, P.; Vakili, B.; Mirhendi, H.; Sadeghi, S.; Hajiahmadi, S.; Sadeghi, A.; Vaezi, A.; Badali, H.; Fakhim, H. Fatal Invasive Pulmonary Aspergillosis in COVID-19 Patient with Acute Myeloid Leukemia in Iran. Mycopathologia 2020, 185, 1077-1084. [CrossRef]

101. Martín, C.S.; Martíne, E.M.; Pellicer, R.G.; Ibáñez, R.A.; González, E.M.; Pitarch, J. Aspergilosis pulmonar invasiva en pacientes con sindrome de distrès respiratorio por COVID-19. Rev. Esp. Anestesiol. Reanim. 2021. [CrossRef]

102. Alobaid, K.; Yousuf, B.; Al-Qattan, E.; Muqeem, Z.; Al-Subaie, N. Pulmonary aspergillosis in two COVID-19 patients from Kuwait. Access Microbiol. 2021, 3, 000201. [CrossRef] [PubMed]

103. Blot, S.I.; Taccone, F.S.; Van den Abeele, A.M.; Bulpa, P.; Meersseman, W.; Brusselaers, N.; Dimopoulos, G.; Paiva, J.A.; Misset, B.; Rello, J.; et al. A Clinical Algorithm to Diagnose Invasive Pulmonary Aspergillosis in Critically Ill Patients. Am. J. Respir. Crit. Care Med. 2012, 186, 56-64. [CrossRef] [PubMed]

104. Verweij, P.E.; Rijnders, B.; Brüggemann, R.; Azoulay, E.; Bassetti, M.; Blot, S.; Calandra, T.; Clancy, C.J.; Cornely, O.A.; Chiller, T.; et al. Review of influenza-associated pulmonary aspergillosis in ICU patients and proposal for a case definition: An expert opinion. Int. Care Med. 2020, 46, 1524-1535. [CrossRef] [PubMed]

105. Schauwvlieghe, A.; Rijnders, B.; Philips, N.; Verwijs, R.; Vanderbeke, L.; Van Tienen, C.; Lagrou, K.; Verweij, P.E.; Van de Veerdonk, F.L.; Gommers, D.; et al. Invasive aspergillosis in patients admitted to the intensive care unit with severe influenza: A retrospective cohort study. Lancet Respir. Med. 2018, 6, 782-792. [CrossRef]

106. Koehler, P.; Bassetti, M.; Chakrabarti, A.; Chen, S.; Colombo, A.L.; Hoenigl, M.; Klimko, N.; Lass-Flörl, C.; Oladele, R.O.; Vinh, D.C.; et al. Defining and managing COVID-19-associated pulmonary aspergillosis: The 2020 ECMM/ISHAM consensus criteria for research and clinical guidance. Lancet Infect. Dis. 2021, 21, e149-e162. [CrossRef]

107. Donnelly, J.P.; Chen, S.C.; Kauffman, C.A.; Steinbach, W.J.; Baddley, J.W.; Verweij, P.E.; Clancy, C.J.; Wingard, J.R.; Lockhart, S.R.; Groll, A.H.; et al. Revision and Update of the Consensus Definitions of Invasive Fungal Disease From the European Organization for Research and Treatment of Cancer and the Mycoses Study Group Education and Research Consortium. Clin. Infect. Dis. 2020, 71, 1367-1376. [CrossRef] [PubMed]

108. Al-Hatmi, A.M.S.; Mohsin, J.; Al-Huraizi, A.; Khamis, F. COVID-19 associated invasive candidiasis. J. Infect. 2021, 82, e45-e46. [CrossRef]

109. Antinori, S.; Bonazzetti, C.; Gubertini, G.; Capetti, A.; Pagani, C.; Morena, V.; Rimoldi, S.; Galimberti, L.; Sarzi-Puttini, P.; Ridolfo, A.L. Tocilizumab for cytokine storm syndrome in COVID-19 pneumonia: An increased risk for candidaemia? Autoimmun. Rev. 2020, 19, 102564. [CrossRef]

110. Khatib, M.Y.; Ahmed, A.A.; Shaat, S.B.; Mohamed, A.S.; Nashwan, A.J. Cryptococcemia in a patient with COVID-19: A case report. Clin. Case Rep. 2021, 9, 853-855. [CrossRef] [PubMed]

111. Alataby, H.; Atemnkeng, F.; Bains, S.S.; Kenne, F.M.; Diaz, K.; Nfonoyim, J. A COVID-19 Case Complicated by Candida dubliniensis and Klebsiella pneumoniae -Carbapenem-Resistant Enterobacteriaceae. J. Med. Cases 2020, 11, 403-406. [CrossRef] [PubMed] 
112. Allaw, F.; Zahreddine, N.K.; Ibrahim, A.; Tannous, J.; Taleb, H.; Bizri, A.R.; Dbaibo, G.; Kanj, S.S. First Candida auris Outbreak during a COVID-19 Pandemic in a Tertiary-Care Center in Lebanon. Pathogens 2021, 10, 157. [CrossRef] [PubMed]

113. Bhagali, R.; Prabhudesai, N.; Prabhudesai, M. Post COVID-19 opportunistic candida retinitis: A case report. Indian J. Ophthalmol. 2021, 69, 987. [CrossRef]

114. De Almeida, J.N., Jr.; Brandão, I.B.; Francisco, E.C.; de Almeida, S.; de Oliveira Dias, P.; Pereira, F.M.; Ferreira, F.S.; de Andrade, T.S.; de Miranda Costa, M.M.; de Souza Jordão, R.T.; et al. Axillary Digital Thermometers uplifted a multidrug-susceptible Candida auris outbreak among COVID-19 patients in Brazil. Mycoses 2021, 64, 1062-1072. [CrossRef] [PubMed]

115. Riche, C.V.W.; Cassol, R.; Pasqualotto, A.C. Is the Frequency of Candidaemia Increasing in COVID-19 Patients Receiving Corticosteroids? J. Fungi 2020, 6, 286. [CrossRef]

116. Sari, A.P.; Darnindro, N.; Yohanes, A.; Mokoagow, M.I. Role of tocilizumab for concomitant systemic fungal infection in severe COVID-19 patient: Case report. Medicine (Baltimore) 2021, 100, e25173. [CrossRef] [PubMed]

117. Tafti, D.; Kluckman, M.; Dearborn, M.C.; Hunninghake, J.; Clayton, S. COVID-19 in Patients with Hematologic-Oncologic Risk Factors: Complications in Three Patients. Cureus 2020, 12, e12064. [PubMed]

118. Ventoulis, I.; Sarmourli, T.; Amoiridou, P.; Mantzana, P.; Exindari, M.; Gioula, G.; Vyzantiadis, T.A. Bloodstream Infection by Saccharomyces cerevisiae in Two COVID-19 Patients after Receiving Supplementation of Saccharomyces in the ICU. J. Fungi 2020, 6, 98. [CrossRef] [PubMed]

119. Villanueva-Lozano, H.; Treviño-Rangel, R.D.J.; González, G.M.; Ramírez-Elizondo, M.T.; Lara-Medrano, R.; Aleman-Bocanegra, M.C.; Guajardo-Lara, C.E.; Gaona-Chavez, N.; Castilleja-Leal, F.; Torre-Amione, G.; et al. Outbreak of Candida auris infection in a COVID-19 hospital in Mexico. Clin. Microbiol. Infect. 2021, 27, 813-816. [CrossRef]

120. Al Argan, R.J.; Alqatari, S.G.; Al Said, A.H.; Alsulaiman, R.M.; Noor, A.; Al Sheekh, L.A.; Al Beladi, F.H. Gastrointestinal perforation secondary to COVID-19: Case reports and literature review. Medicine 2021, 100, e25771. [CrossRef]

121. Görkem, A.; Sav, H.; Kaan, Ö.; Eren, E. Coronavirus disease and candidaemia infection: A case report. J. Med. Mycol. 2021, 31, 101155. [CrossRef]

122. Awada, B.; Alam, W.; Chalfoun, M.; Araj, G.; Bizri, A.R. COVID-19 and Candida duobushaemulonii superinfection: A case report. J. Med. Mycol. 2021, 31, 101168. [CrossRef]

123. Gorospe-Sarasúa, L.; Gallego-Rivera, J.I.; Muñoz-Molina, G.M.; Mirambeaux-Villalona, R.M.; Ajuria-Illarramendi, O.; GonzálezGarcía, A.; Barbolla-Diaz, I. Costocondritis y espondilitis diferidas por Candida en paciente post-COVID-19 tratado previamente con corticoides, antibióticos y tocilizumab. Arch. Bronconeumol. 2021, 57, 48-50. [CrossRef] [PubMed]

124. Chowdhary, A.; Tarai, B.; Singh, A.; Sharma, A. Multidrug-Resistant Candida auris Infections in Critically Ill Coronavirus Disease Patients, India, April-July 2020. Emerg. Infect. Dis. 2020, 26, 2694-2696. [CrossRef] [PubMed]

125. Bishburg, E.; Okoh, A.; Nagarakanti, S.R.; Lindner, M.; Migliore, C.; Patel, P. Fungemia in COVID-19 ICU patients, a single medical center experience. J. Med. Virol. 2021, 93, 2810-2814. [CrossRef] [PubMed]

126. Hughes, S.; Troise, O.; Donaldson, H.; Mughal, N.; Moore, L.S.P. Bacterial and fungal coinfection among hospitalized patients with COVID-19: A retrospective cohort study in a UK secondary-care setting. Clin. Microbiol. Infect. 2020, 26, 1395-1399. [CrossRef] [PubMed]

127. Posteraro, B.; Torelli, R.; Vella, A.; Leone, P.M.; De Angelis, G.; De Carolis, E.; Ventura, G.; Sanguinetti, M.; Fantoni, M. PanEchinocandin-Resistant Candida glabrata Bloodstream Infection Complicating COVID-19: A Fatal Case Report. J. Fungi 2020, 6, 163. [CrossRef] [PubMed]

128. Mastrangelo, A.; Germinario, B.N.; Ferrante, M.; Frangi, C.; Voti, R.L.; Muccini, C.; Ripa, M.; COVID-BioB Study Group. Candidaemia in Coronavirus Disease 2019 (COVID-19) Patients: Incidence and Characteristics in a Prospective Cohort Compared with Historical Non-COVID-19 Controls. Clin. Infect. Dis 2020, ciaa1594. [CrossRef]

129. Cataldo, M.A.; Tetaj, N.; Selleri, M.; Marchioni, L.; Capone, A.; Caraffa, E.; Caro, A.D.; Petrosillo, N.; INMICOVID-19 Co-infection Group. Incidence of bacterial and fungal bloodstream infections in COVID-19 patients in intensive care: An alarming "collateral effect". J. Glob. Antimicrob. Resist. 2020, 23, 290-291. [CrossRef] [PubMed]

130. Giacobbe, D.R.; Battaglini, D.; Ball, L.; Brunetti, I.; Bruzzone, B.; Codda, G.; Crea, F.; De Maria, A.; Dentone, C.; Di Biagio, A.; et al. Bloodstream infections in critically ill patients with COVID-19. Eur. J. Clin. Investig. 2020, 50, e13319. [CrossRef] [PubMed]

131. Nucci, M.; Barreiros, G.; Guimarães, L.F.; Deriquehem, V.A.S.; Castiñeiras, A.C.; Nouér, S.A. Increased incidence of candidaemia in a tertiary care hospital with the COVID-19 pandemic. Mycoses 2021, 64, 152-156. [CrossRef] [PubMed]

132. Magnasco, L.; Mikulska, M.; Giacobbe, D.R.; Taramasso, L.; Vena, A.; Dentone, C.; Dettori, S.; Tutino, S.; Labate, L.; Di Pilato, V.; et al. Spread of Carbapenem-Resistant Gram-Negatives and Candida auris during the COVID-19 Pandemic in Critically Ill Patients: One Step Back in Antimicrobial Stewardship? Microorganisms 2021, 9, 95. [CrossRef] [PubMed]

133. Arastehfar, A.; Shaban, T.; Zarrinfar, H.; Roudbary, M.; Ghazanfari, M.; Hedayati, M.T.; Sedaghat, A.; LLkit, M.; Najafzadeh, M.J.; Perlin, D.S. Candidaemia among Iranian Patients with Severe COVID-19 Admitted to ICUs. J. Fungi 2021, 7, 280. [CrossRef] [PubMed]

134. Silva, D.L.; Lima, C.M.; Magalhães, V.C.R.; Baltazar, L.M.; Peres, N.T.A.; Caligiorne, R.B.; Moura, A.S.; Fereguetti, T.; Martins, J.C.; Rabelo, L.F.; et al. Fungal and bacterial coinfections increase mortality of severely ill COVID-19 patients. J. Hosp. Infect. 2021, 113, 145-154. [CrossRef] [PubMed]

135. Rodriguez, J.Y.; Le Pape, P.; Lopez, O.; Esquea, K.; Labiosa, A.L.; Alvarez-Moreno, C. Candida auris: A latent threat to critically ill patients with COVID-19. Clin. Infect. Dis. 2020, ciaa1595. [CrossRef] 
136. Macauley, P.; Epelbaum, O. Epidemiology and Mycology of Candidaemia in non-oncological medical intensive care unit patients in a tertiary center in the United States: Overall analysis and comparison between non-COVID-19 and COVID-19 cases. Mycoses 2021, 64, 634-640. [CrossRef]

137. Zhang, H.; Zhang, Y.; Wu, J.; Li, Y.; Zhou, X.; Li, X.; Chen, H.; Guo, M.; Chen, S.; Sun, F.; et al. Risks and features of secondary infections in severe and critical ill COVID-19 patients. Emerg. Microbes Infect. 2020, 9, 1958-1964. [CrossRef] [PubMed]

138. Zurl, C.; Hoenigl, M.; Schulz, E.; Hatzl, S.; Gorkiewicz, G.; Krause, R.; Eller, P.; Prattes, J. Autopsy Proven Pulmonary Mucormycosis Due to Rhizopus microsporus in a Critically Ill COVID-19 Patient with Underlying Hematological Malignancy. J. Fungi 2021, 7, 88. [CrossRef]

139. Garg, D.; Muthu, V.; Sehgal, I.S.; Ramachandran, R.; Kaur, H.; Bhalla, A.; Puri, G.D.; Chakrabarti, A.; Agarwal, R. Coronavirus Disease (Covid-19) Associated Mucormycosis (CAM): Case Report and Systematic Review of Literature. Mycopathologia 2021, 186, 289-298. [CrossRef] [PubMed]

140. Khatri, A.; Chang, K.M.; Berlinrut, I.; Wallach, F. Mucormycosis after Coronavirus disease 2019 infection in a heart transplant recipient-Case report and review of literature. J. Med. Mycol. 2021, 31, 101125. [CrossRef] [PubMed]

141. Pasero, D.; Sanna, S.; Liperi, C.; Piredda, D.; Branca, G.P.; Casadio, L.; Simeo, R.; Busellli, A.; Rizzo, D.; Bussu, F.; et al. A challenging complication following SARS-CoV-2 infection: A case of pulmonary mucormycosis. Infection 2020, 49, 1055-1060. [CrossRef] [PubMed]

142. Arana, C.; Ramírez, R.E.C.; Xipell, M.; Casals, J.; Moreno, A.; Herrera, S.; Bodro, M.; Cofan, F.; Diekmann, F.; Esforzado, N Mucormycosis associated with COVID-19 in two kidney transplant patients. Transpl Infect. Dis. 2021, 23, e13652. [CrossRef] [PubMed]

143. Rao, R.; Shetty, A.; Nagesh, C. Orbital infarction syndrome secondary to rhino-orbital mucormycosis in a case of COVID-19: Clinico-radiological features. Indian J. Ophthalmol. 2021, 69, 1627-1630. [CrossRef] [PubMed]

144. Krishna, V.; Morjaria, J.; Jalandari, R.; Omar, F.; Kaul, S. Autoptic identification of disseminated mucormycosis in a young male presenting with cerebrovascular event, multi-organ dysfunction and COVID-19 infection. IDCases 2021, 25, e01172. [CrossRef] [PubMed]

145. Meshram, H.S.; Kute, V.B.; Chauhan, S.; Desai, S. Mucormycosis in post-COVID-19 renal transplant patients: A lethal complication in follow-up. Transpl Infect. Dis. 2021, 23, e13663. [CrossRef]

146. Nehara, H.R.; Puri, I.; Singhal, V.; Ih, S.; Bishnoi, B.R.; Sirohi, P. Rhinocerebral mucormycosis in COVID-19 patient with diabetes a deadly trio: Case series from the north-western part of India. Indian J. Med. Microbiol. 2021, 39, 380-383. [CrossRef]

147. Buil, J.B.; van Zanten, A.R.H.; Bentvelsen, R.G.; Rijpstra, T.A.; Goorhuis, B.; van der Voort, S.; Wammes, L.J.; Janson, J.A.; Melchers, M.; Heusinkveld, M.; et al. Case series of four secondary mucormycosis infections in COVID-19 patients, the Netherlands, December 2020 to May 2021. Eurosurveillance 2021, 26, 2100510. [CrossRef]

148. Ashour, M.M.; Abdelaziz, T.T.; Ashour, D.M.; Askoura, A.; Saleh, M.I.; Mahmoud, M.S. Imaging spectrum of acute invasive fungal rhino-orbital-cerebral sinusitis in COVID-19 patients: A case series and a review of literature. J. Neuroradiol. 2021, 48, 319-324. [CrossRef]

149. Kanwar, A.; Jordan, A.; Olewiler, S.; Wehberg, K.; Cortes, M.; Jackson, B.R. A Fatal Case of Rhizopus azygosporus Pneumonia Following COVID-19. J. Fungi 2021, 7, 174. [CrossRef]

150. Placik, D.A.; Taylor, W.L.; Wnuk, N.M. Bronchopleural fistula development in the setting of novel therapies for acute respiratory distress syndrome in SARS-CoV-2 pneumonia. Radiol. Case Rep. 2020, 15, 2378-2381. [CrossRef] [PubMed]

151. Veisi, A.; Bagheri, A.; Eshaghi, M.; Rikhtehgar, M.H.; Rezaei Kanavi, M.; Farjad, R. Rhino-orbital mucormycosis during steroid therapy in COVID-19 patients: A case report. Eur. J. Ophthalmol. 2021. [CrossRef]

152. Saldanha, M.; Reddy, R.; Vincent, M.J. Paranasal Mucormycosis in COVID-19 Patient. Indian J. Otolaryngol Head Neck Surg. 2021, 1-4. [CrossRef]

153. Revannavar, S.M.; Supriya, P.S.; Samaga, L.; Vineeth, V.K. COVID-19 triggering mucormycosis in a susceptible patient: A new phenomenon in the developing world? BMJ Case Rep. 2021, 14, e241663. [CrossRef]

154. Maini, A.; Tomar, G.; Khanna, D.; Kini, Y.; Mehta, H.; Bhagyasree, V. Sino-orbital mucormycosis in a COVID-19 patient: A case report. Int. J. Surg. Case Rep. 2021, 82, 105957. [CrossRef] [PubMed]

155. Alekseyev, K.; Didenko, L.; Chaudhry, B. Rhinocerebral Mucormycosis and COVID-19 Pneumonia. J. Med. Cases. 2021, 12, 85-89. [CrossRef] [PubMed]

156. Krishna, D.S.; Raj, H.; Kurup, P.; Juneja, M. Maxillofacial Infections in Covid-19 Era—Actuality or the Unforeseen: 2 Case Reports. Indian J. Otolaryngol. Head Neck Surg. 2021, 1-4. [CrossRef]

157. Werthman-Ehrenreich, A. Mucormycosis with orbital compartment syndrome in a patient with COVID-19. Am. J. Emerg. Med. 2021, 42, 264.e5-264.e8. [CrossRef] [PubMed]

158. Hanley, B.; Naresh, K.N.; Roufosse, C.; Nicholson, A.G.; Weir, J.; Cooke, G.S.; Thursz, M.; Manousou, P.; Corbett, R.; Goldin, R.; et al. Histopathological findings and viral tropism in UK patients with severe fatal COVID-19: A post-mortem study. Lancet Microbe 2020, 1, e245-e253. [CrossRef]

159. Mehta, S.; Pandey, A. Rhino-Orbital Mucormycosis Associated With COVID-19. Cureus 2020, 12, e10726. [CrossRef] [PubMed]

160. do Monte Junior, E.S.; dos Santos, M.E.L.; Ribeiro, I.B.; Luz, G.d.O.; Baba, E.R.; Hirsch, B.S.; Funari, M.P.; de Moura, E.G.H. Rare and Fatal Gastrointestinal Mucormycosis (Zygomycosis) in a COVID-19 Patient: A Case Report. Clin. Endosc. 2020, 53, 746-749. [CrossRef] [PubMed] 
161. Mekonnen, Z.K.; Ashraf, D.C.; Jankowski, T.; Grob, S.R.; Vagefi, M.R.; Kersten, R.C.; Simko, J.P.; Winn, B.J. Acute Invasive Rhino-Orbital Mucormycosis in a Patient With COVID-19-Associated Acute Respiratory Distress Syndrome. Ophthal. Plast Reconstr. Surg. 2021, 37, e40-e80. [CrossRef] [PubMed]

162. Selarka, L.; Sharma, A.K.; Rathod, G.; Saini, D.; Patel, S.; Sharma, V.K. Mucormycosis- A Dreaded Complication Of Covid-19. QJM Int. J. Med. 2021, hcab166. [CrossRef] [PubMed]

163. Sarkar, S.; Gokhale, T.; Choudhury, S.S.; Deb, A.K. COVID-19 and orbital mucormycosis. Indian J. Ophthalmol. 2021, 69, 1002-1004. [PubMed]

164. Karimi-Galougahi, M.; Arastou, S.; Haseli, S. Fulminant mucormycosis complicating coronavirus disease 2019 (COVID-19). Int. Forum. Allergy Rhinol. 2021, 11, 1029-1030. [CrossRef] [PubMed]

165. Dallalzadeh, L.O.; Ozzello, D.J.; Liu, C.Y.; Kikkawa, D.O.; Korn, B.S. Secondary infection with rhino-orbital cerebral mucormycosis associated with COVID-19. Orbit 2021, 1-4. [CrossRef] [PubMed]

166. Waizel-Haiat, S.; Guerrero-Paz, J.A.; Sanchez-Hurtado, L.; Calleja-Alarcon, S.; Romero-Gutierrez, L. A Case of Fatal Rhino-Orbital Mucormycosis Associated with New Onset Diabetic Ketoacidosis and COVID-19. Cureus 2021, 13, e13163. [PubMed]

167. Khan, N.; Gutierrez, C.G.; Martinez, D.V.; Proud, K.C. A case report of COVID-19 associated pulmonary mucormycosis. Arch. Clin. Cases 2020, 07, 46-51. [CrossRef]

168. Pauli, M.A.; de Melo Pereira, L.; Monteiro, M.L.; de Camargo, A.R.; Rabelo, G.D. Painful palatal lesion in a patient with COVID-19. Oral Surg. Oral Med. Oral Pathol. Oral Radiol. 2021, 131, 620-625. [CrossRef]

169. Ravani, S.; Agrawal, G.; Leuva, P.; Modi, P.; Amin, K. Rise of the phoenix: Mucormycosis in COVID-19 times. Indian J. Ophthalmol. 2021, 69, 1563. [PubMed]

170. Sen, M.; Lahane, S.; Lahane, T.; Parekh, R.; Honavar, S. Mucor in a Viral Land: A Tale of Two Pathogens. Indian J. Ophthalmol. 2021, 69, 244-252. [PubMed]

171. Pakdel, F.; Ahmadikia, K.; Salehi, M.; Tabari, A.; Jafari, R.; Mehrparvar, G.; Rezaie, Y.; Rajaeih, S.; Alijani, N.; BArac, A.; et al. Mucormycosis in patients with COVID-19: A cross-sectional descriptive multicenter study from Iran. Mycoses 2021, 64, 1238-1252. [CrossRef] [PubMed]

172. Moorthy, A.; Gaikwad, R.; Krishna, S.; Hegde, R.; Tripathi, K.K.; Kale, P.G.; Rao, P.S.; Haldipur, D.; Bonanthaya, K. SARS-CoV-2, Uncontrolled Diabetes and Corticosteroids-An Unholy Trinity in Invasive Fungal Infections of the Maxillofacial Region? A Retrospective, Multi-centric Analysis. J. Maxillofac. Oral. Surg. 2021, 20, 418-425. [CrossRef] [PubMed]

173. Sharma, S.; Grover, M.; Bhargava, S.; Samdani, S.; Kataria, T. Post coronavirus disease mucormycosis: A deadly addition to the pandemic spectrum. J. Laryngol. Otol. 2021, 135, 442-447. [CrossRef] [PubMed]

174. Ismaiel, W.F.; Abdelazim, M.H.; Eldsoky, I.; Ibrahim, A.A.; Alsobky, M.E.; Zafan, E.; Hasan, A. The impact of COVID-19 outbreak on the incidence of acute invasive fungal rhinosinusitis. Am. J. Otolaryngol. 2021, 42, 103080. [CrossRef] [PubMed]

175. Fouad, Y.A.; Abdelaziz, T.T.; Askoura, A.; Saleh, M.I.; Mahmoud, M.S.; Ashour, D.M.; Ashour, M.M. Spike in Rhino-OrbitalCerebral Mucormycosis Cases Presenting to a Tertiary Care Center During the COVID-19 Pandemic. Front. Med. 2021, 8, 645270. [CrossRef]

176. Patel, A.; Agarwal, R.; Rudramurthy, S.; Shevkani, M.; Xess, I.; Sharma, R.; Savio, J.; Setheraman, N.; Madan, S.; Shastri, P.; et al. Multicenter Epidemiologic Study of Coronavirus Disease-Associated Mucormycosis, India. Emerg. Infect. Dis. J. 2021, 27, 2349-2359. [CrossRef] [PubMed]

177. Sen, M.; Honavar, S.G.; Bansal, R.; Sengupta, S.; Rao, R.; Kim, U.; Sharma, M.; Sachdev, M.; Grover, A.K.; Surve, A.; et al. Epidemiology, clinical profile, management, and outcome of COVID-19-associated rhino-orbital-cerebral mucormycosis in 2826 patients in India-Collaborative OPAI-IJO Study on Mucormycosis in COVID-19 (COSMIC), Report 1. Indian J. Ophthal. 2021, 69, 1670-1692.

178. Broadhurst, A.G.B.; Lalla, U.; Taljard, J.J.; Louw, E.H.; Koegelenberg, C.F.F.; Allwood, B.W. The diagnostic challenge of pneumocystis pneumonia and COVID-19 co-infection in HIV. Resp. Case Rep. 2021, 9, e00725.

179. Menon, A.A.; Berg, D.D.; Brea, E.J.; Deutsch, A.J.; Kidia, K.K.; Thurber, E.G.; Polsky, S.B.; Yeh, T.; Duskin, J.A.; Holliday, A.M.; et al. A Case of COVID-19 and Pneumocystis jirovecii Coinfection. Am. J. Respir. Crit. Care Med. 2020, 202, 136-138. [CrossRef] [PubMed]

180. Mang, S.; Kaddu-Mulindwa, D.; Metz, C.; Becker, A.; Seiler, F.; Smola, S.; Mabmann, A.; Becjker, S.L.; Papan, C.; Bals, R.; et al. Pneumocystis jirovecii Pneumonia and Severe Acute Respiratory Syndrome Coronavirus 2 Coinfection in a Patient with Newly Diagnosed HIV-1 Infection. Clin. Infect. Dis. 2020, 72, 1487-1489. [CrossRef]

181. Bhat, P.; Noval, M.; Doub, J.B.; Heil, E. Concurrent COVID-19 and Pneumocystis jirovecii pneumonia in a severely immunocompromised 25-year-old patient. Int. J. Infect. Dis. 2020, 99, 119-121. [CrossRef] [PubMed]

182. De Francesco, M.A.; Alberici, F.; Bossini, N.; Scolari, F.; Pascucci, F.; Tomasoni, G.; Caruso, A. Pneumocystis jirevocii and SARS-CoV-2 Co-Infection: A Common Feature in Transplant Recipients? Vaccines 2020, 8, 544. [CrossRef] [PubMed]

183. Alanio, A.; Dellière, S.; Voicu, S.; Bretagne, S.; Mégarbane, B. The presence of Pneumocystis jirovecii in critically ill patients with COVID-19. J. Infect. 2021, 82, 84-123. [CrossRef] [PubMed]

184. Jeican, I.I.; Inișca, P.; Gheban, D.; Tăbăran, F.; Aluaș, M.; Trombitas, V.; Cristea, V.; Crivii, C.; Junie, L.M.; Albu, S. COVID-19 and Pneumocystis jirovecii Pulmonary Coinfection-The First Case Confirmed through Autopsy. Medicina 2021, 57, 302. [CrossRef] [PubMed]

185. Coleman, H.; Snell, L.B.; Simons, R.; Douthwaite, S.T.; Lee, M.J. Coronavirus disease 2019 and Pneumocystis jirovecii pneumonia: A diagnostic dilemma in HIV. AIDS 2020, 34, 1258-1260. [CrossRef] [PubMed] 
186. Rubiano, C.; Tompkins, K.; Sellers, S.A.; Bramson, B.; Eron, J.; Parr, J.B.; Schranz, A.J. Pneumocystis and Severe Acute Respiratory Syndrome Coronavirus 2 Coinfection: A Case Report and Review of an Emerging Diagnostic Dilemma. Open Forum Infect. Dis. 2021, 8, ofaa633. [CrossRef] [PubMed]

187. Viceconte, G.; Buonomo, A.R.; Lanzardo, A.; Pinchera, B.; Zappulo, E.; Scotto, R.; Schiano Moriello, N.; Vargas, M.; Iacovazzo, C.; Servillo, G.; et al. Pneumocystis jirovecii pneumonia in an immunocompetent patient recovered from COVID-19. Infect. Dis. 2021, 53, 382-385. [CrossRef]

188. Larzábal, F.J.; Vilela, A.; Brusca, S.; Saluzzi, I.; Ghergo, G.E.; Angiono, M.A. Diagnóstico simultáneo y evolución favorable de infección por Pneumocystis jirovecii, SARS-COV-2 y HIV avanzada [Simultaneous diagnosis and favorable evolution of infection with Pneumocystis jirovecii, SARS-CoV-2 and advanced HIV]. Medicina (B Aires) 2020, 80, 554-556. [PubMed]

189. Woldie, I.L.; Brown, I.G.; Nwadiaro, N.F.; Patel, A.; Jarrar, M.; Quint, E.; Khokhotva, V.; Hugel, N.; Winger, M.; Briskin, A. Autoimmune Hemolytic Anemia in a 24-Year-Old Patient With COVID-19 Complicated by Secondary Cryptococcemia and Acute Necrotizing Encephalitis: A Case Report and Review of Literature. J. Med. Cases. 2020, 11, 362-365. [CrossRef] [PubMed]

190. Passarelli, V.C.; Perosa, A.H.; de Souza Luna, L.K.; Conte, D.D.; Nascimento, O.A.; Ota-Arakaki, J.; Bellei, N. Detected SARS-CoV-2 in Ascitic Fluid Followed by Cryptococcemia: A Case Report. SN Compr. Clin. Med. 2020, 2, 2414-2418. [CrossRef]

191. Ghanem, H.; Sivasubramanian, G. Cryptococcus neoformans Meningoencephalitis in an Immunocompetent Patient after COVID-19 Infection. Case Rep. Infect. Dis. 2021, 2021, 5597473.

192. Messina, F.A.; Marin, E.; Caceres, D.H.; Romero, M.; Depardo, R.; Priarone, M.M.; Rey, L.; Vázquez, M.; Verweij, P.E.; Chiller, T.M.; et al. Coronavirus Disease 2019 (COVID-19) in a Patient with Disseminated Histoplasmosis and HIV-A Case Report from Argentina and Literature Review. J. Fungi 2020, 6, 275. [CrossRef] [PubMed]

193. de Macedo, P.M.; Freitas, A.D.; Bártholo, T.P.; Bernardes-Engemann, A.R.; de Abreu Almeida, M.; Almeida-Silva, F.; ZancopèOliveira, R.M.; Almeida-Paes, R. Acute Pulmonary Histoplasmosis Following COVID-19: Novel Laboratorial Methods Aiding Diagnosis. J. Fungi 2021, 7, 346. [CrossRef]

194. Bertolini, M.; Mutti, M.F.; Barletta, J.A.; Falak, A.; Cuatz, D.; Sisto, A.; Ragusa, M.A.; Fernandez Claros, N.O.; Rolón, M.J. COVID-19 associated with AIDS-related disseminated histoplasmosis: A case report. Int. J. STD AIDS 2020, 31, 1222-1224. [CrossRef] [PubMed]

195. Basso, R.P.; Poester, V.R.; Benelli, J.L.; Stevens, D.A.; Zogbi, H.E.; Vasconcellos, I.C.D.S.; Pasqualotto, A.C.; Xavier, M.O. COVID19-Associated Histoplasmosis in an AIDS Patient. Mycopathologia 2020, 186, 109-112. [CrossRef] [PubMed]

196. Shah, A.S.; Heidari, A.; Civelli, V.F.; Sharma, R.; Clark, C.S.; Munoz, A.D.; Ragland, A.S.; Johnson, R.H. The Coincidence of 2 Epidemics, Coccidioidomycosis and SARS-CoV-2: A Case Report. J. Investig Med. High. Impact Case Rep. 2020, 8, 232470962093054. [CrossRef] [PubMed]

197. Christiaansen, A.; Varga, S.M.; Spencer, J.V. Viral manipulation of the host immune response. Curr. Opin. Immunol. 2015, 36, 54-60. [CrossRef] [PubMed]

198. Arvanitis, M.; Anagnostou, T.; Mylonakis, E. Galactomannan and Polymerase Chain Reaction-Based Screening for Invasive aspergillosis Among High-Risk Hematology Patients: A Diagnostic Meta-analysis. Clin. Infect. Dis. 2015, 61, 1263-1272. [CrossRef] [PubMed]

199. Lahmer, T.; Neuenhahn, M.; Held, J.; Rasch, S.; Schmid, R.M.; Huber, W. Comparison of 1,3- $\beta$ - d -glucan with galactomannan in serum and bronchoalveolar fluid for the detection of aspergillus species in immunosuppressed mechanical ventilated critically ill patients. J. Crit. Care 2016, 36, 259-264. [CrossRef] [PubMed]

200. Chong, W.H.; Neu, K.P. Incidence, Diagnosis, and Outcomes of COVID-19-associated Pulmonary aspergillosis (CAPA): A Systematic Review. J. Hosp. Infect. 2021, 113, 115-129. [CrossRef] [PubMed]

201. Mitaka, H.; Kuno, T.; Takagi, H.; Patrawalla, P. Incidence and Mortality of COVID-19-associated Pulmonary aspergillosis: A Systematic Review and Meta-analysis. Mycoses 2021, 64, 993-1001. [CrossRef]

202. Zhou, W.; Li, H.; Zhang, Y.; Huang, M.; He, Q.; Li, P.; Zhang, F.; Shi, Y.; Su, X. Diagnostic Value of Galactomannan Antigen Test in Serum and Bronchoalveolar Lavage Fluid Samples from Patients with Nonneutropenic Invasive Pulmonary Aspergillosis. J. Clin. Microbiol. 2017, 55, 2153-2161. [CrossRef] [PubMed]

203. Farmakiotis, D.; Le, A.; Weiss, Z.; Ismail, N.; Kubiak, D.W.; Koo, S. False positive bronchoalveolar lavage galactomannan: Effect of host and cut-off value. Mycoses 2019, 62, 204-213. [CrossRef] [PubMed]

204. Huang, L.; He, H.; Ding, Y.; Jin, J.; Zhan, Q. Values of radiological examinations for the diagnosis and prognosis of invasive bronchial-pulmonary aspergillosis in critically ill patients with chronic obstructive pulmonary diseases. Clin. Respir. J. 2018, 12, 499-509. [CrossRef] [PubMed]

205. Kula, B.E.; Clancy, C.J.; Nguyen, M.H.; Schwartz, I.S. Invasive mould disease in fatal COVID-19: A systematic review of autopsies. Lancet Microbe 2021, 2, e405-414. [CrossRef]

206. Evert, K.; Dienemann, T.; Brochhausen, C.; Lunz, D.; Lubnow, M.; Ritzka, M.; Keil, F.; Trummer, M.; Scheiter, A.; Salzberger, B.; et al. Autopsy findings after long-term treatment of COVID-19 patients with microbiological correlation. Virchows Arch. 2021, 479, 97-108. [CrossRef] [PubMed]

207. Zhang, Z.; Zhu, R.; Luan, Z.; Ma, X. Risk of invasive candidiasis with prolonged duration of ICU stay: A systematic review and meta-analysis. BMJ Open. 2020, 10, e036452. [CrossRef] [PubMed] 
208. Koehler, P.; Stecher, M.; Cornely, O.A.; Koehler, D.; Vehreschild, M.J.G.T.; Bohlius, J.; Wisplinghoff, H.; Vehreschild, J.J. Morbidity and mortality of candidaemia in Europe: An epidemiologic meta-analysis. Clin. Microbiol. Infect. 2019, 25, 1200-1212. [CrossRef] [PubMed]

209. McCarty, T. Candidaemia and Severe COVID-19-Which Risk Factors are Modifiable? Clin. Infect. Dis. 2021, ciab635. [CrossRef] [PubMed]

210. Prakash, H.; Chakrabarti, A. Global Epidemiology of Mucormycosis. J. Fungi 2019, 5, 26. [CrossRef] [PubMed]

211. Skiada, A.; Pavleas, I.; Drogari-Apiranthitou, M. Epidemiology and Diagnosis of Mucormycosis: An Update. J. Fungi 2020, 6, 265. [CrossRef] [PubMed]

212. Narayanan, S.; Chua, J.V.; Baddley, J.W. COVID-19 associated Mucormycosis (CAM): Risk factors and mechanisms of disease. Clin. Infect. Dis. 2021, ciab726. [CrossRef] [PubMed]

213. Malhotra, H.S.; Gupta, P.; Mehrotra, D.; Dandu, H.; Kohli, N.; Verma, V.; Kaur, A.; Kumar, N.; Prabhu, V.; Singh, M.K.; et al. COVID-19 associated mucormycosis: Staging and management recommendations (Report of a multi-disciplinary expert committee). J. Oral Biol. Craniofacial Res. 2021, 11, 569-580. [CrossRef] [PubMed]

214. Rudramurthy, S.M.; Hoenigl, M.; Meis, J.F.; Cornely, O.A.; Muthu, V.; Gangneux, J.P.; Perfect, J.; Chakrabarti, A.; ECMM; ISHAM. ECMM/ISHAM recommendations for clinical management of COVID-19 associated mucormycosis in low- and middle-income countries. Mycoses 2021, 64, 1028-1037. [CrossRef] [PubMed]

215. Al-Tawfiq, J.A.; Alhumaid, S.; Alshukairi, A.N.; Temsah, M.N.; Barry, M.; Al Mutair, A.; Rabaan, A.A.; Al-Omari, A.; Tirupathi, R.; AlQahtani, M.; et al. COVID-19 and mucormycosis superinfection: The perfect storm. Infection 2021, 49, 833-853. [CrossRef] [PubMed]

216. COVID-19 Treatment Guidelines Panel. Coronavirus Disease 2019 (COVID-19) Treatment Guidelines; National Institutes of Health: Bethesda, MD, USA, 2021. Available online: https://www.covid19treatmentguidelines.nih.gov (accessed on 18 October 2021). 